\title{
In-situ measurements of oxygen, carbon monoxide and greenhouse gases from Ochsenkopf tall tower in Germany
}

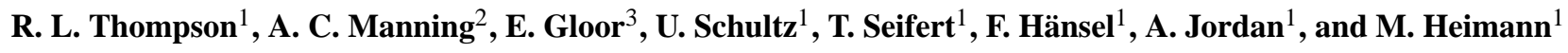 \\ ${ }^{1}$ Max Planck Institute for Biogeochemistry, Jena, Germany \\ ${ }^{2}$ School of Environmental Sciences, University of East Anglia, Norwich, UK \\ ${ }^{3}$ University of Leeds, Leeds, UK
}

Received: 27 March 2009 - Published in Atmos. Meas. Tech. Discuss.: 5 May 2009

Revised: 31 August 2009 - Accepted: 11 September 2009 - Published: 23 October 2009

\begin{abstract}
We present 2.5 years (from June 2006 to December 2008) of in-situ measurements of $\mathrm{CO}_{2}, \mathrm{O}_{2}, \mathrm{CH}_{4}, \mathrm{CO}$, $\mathrm{N}_{2} \mathrm{O}$ and $\mathrm{SF}_{6}$ mixing ratios sampled from 23, 90 and $163 \mathrm{~m}$ above ground on the Ochsenkopf tower in the Fichtelgebirge range, Germany $\left(50^{\circ} 01^{\prime} 49^{\prime \prime} \mathrm{N}, 11^{\circ} 48^{\prime} 30^{\prime \prime} \mathrm{E}, 1022 \mathrm{~m}\right.$ a.s.l. $)$. In addition to the in-situ measurements, flask samples are taken at Ochsenkopf at approximately weekly intervals and are subsequently analysed for the mixing ratios of the same species, as well as $\mathrm{H}_{2}$, and the stable isotopes, $\delta^{13} \mathrm{C}, \delta^{18} \mathrm{O}$ in $\mathrm{CO}_{2}$. The in-situ measurements of $\mathrm{CO}_{2}$ and $\mathrm{O}_{2}$ from $23 \mathrm{~m}$ show substantial diurnal variations that are modulated by biospheric fluxes, combustion of fossil fuels, and by diurnal changes in the planetary boundary layer height. Measurements from $163 \mathrm{~m}$ exhibit only very weak diurnal variability, as this height (1185 m a.s.l.) is generally above the nocturnal boundary layer. $\mathrm{CH}_{4}, \mathrm{CO}, \mathrm{N}_{2} \mathrm{O}$ and $\mathrm{SF}_{6}$ show little diurnal variation even at $23 \mathrm{~m}$ owing to the absence of any significant diurnal change in the fluxes and the absence of any strong local sources or sinks. From the in-situ record, the seasonal cycles of the gas species have been characterized and the multi-annual trends determined. Because the record is short, the calculation of the trend is sensitive to inter-annual variations in the amplitudes of the seasonal cycles. However, for $\mathrm{CH}_{4}$ a significant change in the growth-rate was detected for 2006.5-2008.5 as compared with the global mean from 1999 to 2006 and is consistent with other recent observations of a renewed increasing global growth rate in $\mathrm{CH}_{4}$ since the beginning of 2007 .
\end{abstract}

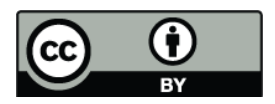

Correspondence to: R. L. Thompson (rthompson@bgc-jena.mpg.de)

\section{Introduction}

There is a strong need for integrated in-situ monitoring systems of the important greenhouse gases (GHG's) $\mathrm{CO}_{2}, \mathrm{CH}_{4}$ and $\mathrm{N}_{2} \mathrm{O}$, in order to determine their fluxes on regional scales. Under the Kyoto Protocol, ratifying countries must quantify anthropogenic emissions of these gases from all sources as well as the uptake by natural sinks (Kyoto Protocol to the United Nations Framework Convention on Climate Change, 1998, http://unfccc.int/resource/docs/convkp/ kpeng.pdf). Furthermore, it is important to be able to monitor the changes in the natural sources and sinks, especially as a response to climatic changes, which will vary from region to region (Denman et al., 2007).

Until recently, atmospheric monitoring networks were not well suited to resolve fluxes on the regional scale. On one hand, the network of coastal stations and satellite observations can be used to estimate global flux patterns, and on the other hand, eddy covariance measurements can be used to calculate local fluxes. Because the horizontal concentration gradients of GHG's in the atmosphere are generally small, accurate and precise measurements are required in order to achieve a sufficiently high signal to noise ratio to constrain regional fluxes. Measurements from coastal station networks exhibit only small temporal and spatial variability, because the strongest sources and sinks are largely over the continents and hence the signals are greatly diluted by the time they reach the marine boundary layer (Gloor et al., 2000). Although these stations are useful for determining global flux patterns and meridional concentration gradients, the signalto-noise ratio from continental fluxes is too small to help resolve regional flux patterns (Gloor et al., 2000). Conversely,

Published by Copernicus Publications on behalf of the European Geosciences Union. 


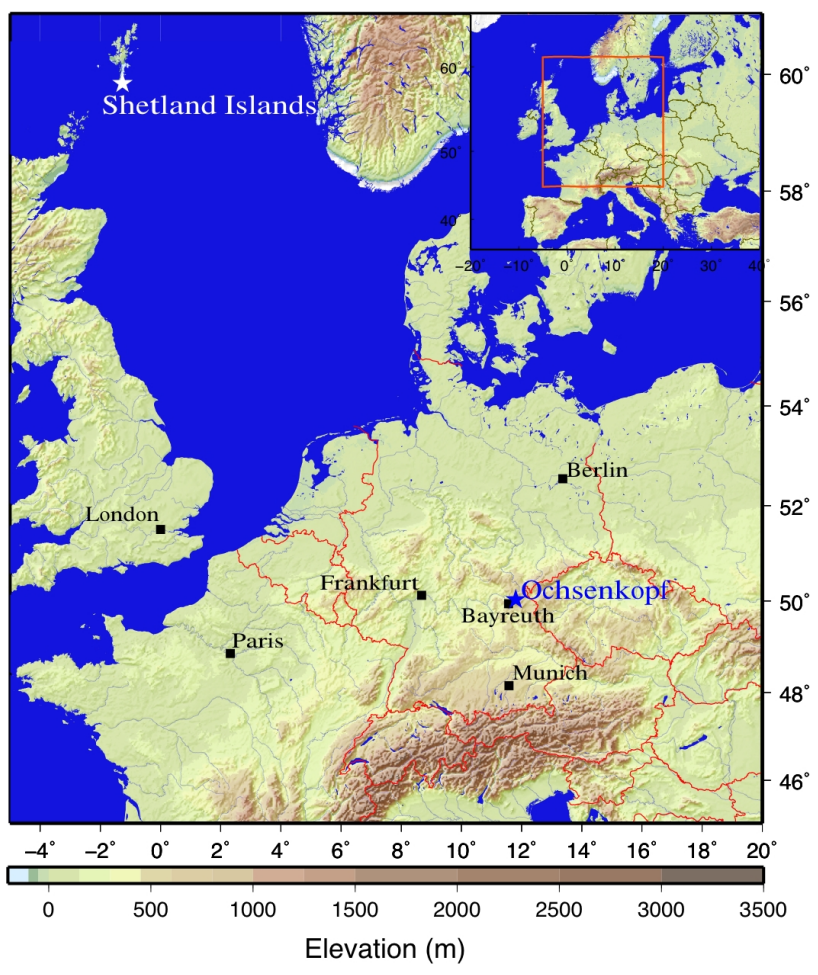

Fig. 1. Elevation map showing the position of Ochsenkopf tall tower and the Shetland Islands' flask sampling site.

fluxes calculated from eddy covariance measurements are only representative of a very small area around the flux tower (of the order of $1-10 \mathrm{~km}^{2}$ ); therefore, data from numerous flux towers need to be integrated or scaled-up to determine regional fluxes. This is usually done with the aid of a model that relates fluxes to, for example, vegetation type and climate, however, the results of this type of integration also need independent validation (Tans et al., 1996).

For these reasons, there has been a move to establish atmospheric measurements over the continents and in the Planetary Boundary Layer (PBL), that is, closer to the strongest anthropogenic emissions and biospheric sources and sinks (Bakwin et al., 1995, 1998). To measure PBL concentrations, the sampling point needs to be above the surface layer (about $100 \mathrm{~m}$ ) in order to minimise the influence of the very nearfield (Gloor et al., 2001), that is, the area within a radius of the order of $10 \mathrm{~km}$. Furthermore, high frequency measurements are required for optimal signal to noise ratio and to resolve diurnal and synoptic variability (Law et al., 2002). Such measurements can be achieved by using tall towers as sampling platforms with in-situ analysers.

From atmospheric concentration records at tall towers, it is possible to observe diurnal and synoptic variability as well as seasonal cycles and multi-annual trends (Bakwin et al., 1995). These data can be used to retrieve spatially and temporally resolved fluxes through the use of an atmospheric in- version model, which accounts for the atmospheric transport and mixing. It is only recently that atmospheric transport models have been developed that can resolve advection and dispersion in the PBL, a necessary feature in order to make use of atmospheric measurements within the PBL (Gerbig et al., 2006).

In the 1990's two continental tall tower sites were established in the USA, in North Carolina and Wisconsin, for in-situ measurements of $\mathrm{CO}_{2}$ and a number of other biogeochemical and anthropogenic trace gases (Bakwin et al., 1995, 1998; Hurst et al., 1997). During this decade, two towers were also established in Europe, Hegyhatsal in Hungary for $\mathrm{CO}_{2}$ (Haszpra et al., 2001) and Cabauw in the Netherlands for $\mathrm{CO}_{2}$ and other trace gases (Vermeulen et al., 2006). From the Wisconsin tower, it has been shown that tall towers can have footprints extending over an area of approximately $10^{6} \mathrm{~km}^{2}$ (Gloor et al., 2001).

However, at the beginning of the 2000's, the European network of in-situ measurement stations remained very sparse. As part of the European-wide project, CHIOTTO (Continuous HIgh-precisiOn Tall Tower Observations of greenhouse gases), an integrated network of tall tower observatories was established for ongoing monitoring of GHG fluxes in Europe. This network includes the two pre-existing stations (Haszpra et al., 2008; Vermeulen et al., 2009) and has five additional ones in France (Schmidt et al., 2009), UK, Poland (Popa et al., 2009), Sweden, and Germany (this paper). During the course of CHIOTTO, a tall tower was also established in Siberia (Kozlova and Manning, 2009) through a separate German funded project but with many parallels, in terms of design, to the CHIOTTO towers.

In this paper, we describe one of the towers in the CHIOTTO network, which is located on the summit, Ochsenkopf, in the Fichtelgebirge range in northern Bavaria, Germany $\left(50^{\circ} 01^{\prime} 49^{\prime \prime} \mathrm{N}, 11^{\circ} 48^{\prime} 30^{\prime \prime} \mathrm{E}\right.$ and $1022 \mathrm{~m}$ a.s.l., see Fig. 1). The Ochsenkopf site was chosen for its relatively high altitude, being the second highest point in the Fichtelgebirge range, thus capturing the signal in the well-mixed PBL, as will be shown in Sect. 3. Additionally, the area surrounding the tower is covered with predominantly conifer forest out to a radius of about $100 \mathrm{~km}$ and lies in an agricultural region that has a relatively low population, about 10 people per $\mathrm{km}^{2}$ (CIESIN Columbia University, http://sedac.ciesin. columbia.edu/gpw).

The tower used at Ochsenkopf is $163 \mathrm{~m}$ tall and is a radio and television transmission tower owned by the Bayerische Rundfunk. Air is sampled at three heights on the tower, 163,90 and $23 \mathrm{~m}$ above ground level and is analysed in-situ in a temperature controlled container-laboratory at the foot of the tower. The species measured are the GHG's: $\mathrm{CO}_{2}$, $\mathrm{CH}_{4}, \mathrm{~N}_{2} \mathrm{O}$ and $\mathrm{SF}_{6}$, and in addition $\mathrm{O}_{2}$ and $\mathrm{CO}$ are measured as tracers for anthropogenic fluxes of $\mathrm{CO}_{2}$. To aid the interpretation of the concentration data, meteorological measurements are also made. Temperature and relative humidity are measured at all heights, with pressure at $90 \mathrm{~m}$, and wind 
speed and direction at $163 \mathrm{~m}$. Furthermore, flask samples are taken at approximately weekly intervals for subsequent analysis of the stable isotopes: $\delta^{13} \mathrm{C}, \delta^{18} \mathrm{O}$ in $\mathrm{CO}_{2}$ and for $\mathrm{H}_{2}$ mixing ratio at the Max Planck Institute for Biogeochemistry (MPI-BGC) in Jena, Germany. The flasks are also analysed for the same species that are measured in-situ, to provide an on-going inter-comparison between the Ochsenkopf station and the MPI-BGC laboratory.

In-situ measurements of $\mathrm{CO}_{2}$ and $\mathrm{O}_{2}$ at Ochsenkopf were originally started in 2002, and measurements of $\mathrm{CH}_{4}, \mathrm{~N}_{2} \mathrm{O}$ and $\mathrm{SF}_{6}$ were made for a few months in 2003 (Jordan et al., 2005), but all measurements were stopped in 2004 owing to ongoing instrumental problems and a shortage of personnel. However, the tower was re-equipped with instruments in 2006 and measurements of all aforementioned species, and $\mathrm{CO}$, have been made continuously since then. We describe the measurement system at Ochsenkopf in place since 2006 and present the results of 2.5 years (June 2006 to December 2008) of continuous $\mathrm{CO}_{2}, \mathrm{O}_{2}, \mathrm{CH}_{4}, \mathrm{CO}, \mathrm{N}_{2} \mathrm{O}$ and $\mathrm{SF}_{6}$ observations.

The paper is structured as follows. In Sect. 2, we describe the instrumentation as well as the air sampling scheme, for example, the flow and pressure control and the air drying system. We then present time series of all gas species and discuss the diurnal, synoptic and seasonal variability in these data. Lastly, we present a case study of one synoptic event and analyse this using a regional atmospheric transport model, STILT (Stochastic Time-Inverted Lagrangian Transport) (Lin et al., 2003).

\section{Methodology}

The in-situ measurement system, shown in Fig. 2, is comprised of three main parts: 1) the air sampling and drying system, 2) the $\mathrm{CO}_{2}$ and $\mathrm{O}_{2}$ instrumentation, and 3) a Gas Chromatograph (GC) for analysis of $\mathrm{CH}_{4}, \mathrm{CO}, \mathrm{N}_{2} \mathrm{O}$ and $\mathrm{SF}_{6}$. The $\mathrm{CO}_{2}$ and $\mathrm{O}_{2}$ instrumentation and the $\mathrm{GC}$ share the same air sampling and drying system.

\subsection{Air sampling and drying system}

Airlines (12 mm outside diameter (OD) Synflex 1300 tubing) for the continuous sampling of all gas species were installed at 3 heights on the tower with inlets at $163 \mathrm{~m}, 90 \mathrm{~m}$ and $23 \mathrm{~m}$ above ground level. Air is drawn continuously through the lines used for $\mathrm{CO}_{2}$ and $\mathrm{O}_{2}$ sampling at a flow-rate of $15 \mathrm{~L} / \mathrm{min}$ using diaphragm pumps (KNF Neuberger Inc, model N828; C1 to C3 in Fig. 2) located inside the containerlaboratory at the foot of the tower. The high flow-rate is used to minimise the residence time of the air in the airlines; in the $163 \mathrm{~m}$ height airline this time is approximately $0.6 \mathrm{~min}$ and the calculated pressure drop is about 60 mbar. Upstream of the pumps, there is a T-junction in each line through which air is drawn at a lower flow-rate of $100 \mathrm{~mL} / \mathrm{min}$ (controlled using needle valves) and provides the air sample for subsequent measurement. Between the pumps and the T-junctions, $10 \mathrm{~m}$ of coiled tubing were used in each line to buffer the pressure pulsations from the pumps at the T-junction (the reasons for this are described in more detail in Sect. 2.2). For the GC, air is drawn continuously through the lines at a lower flow-rate $(100 \mathrm{~mL} / \mathrm{min})$, which results in a long residence time (around $60 \mathrm{~min}$ for the $163 \mathrm{~m}$ level). This was a compromise at the time of installation; owing to limited space, larger pumps to flush the lines were not used. However, the long residence time itself does not produce any sampling artefacts (as is demonstrated in Sect. 3.1). An upgrade of the GC sampling system is planned though, to increase the flow-rate in the lines and reduce the residence time, with the primary motivation of making it easier to compare these measurements with those of $\mathrm{CO}_{2}$ and $\mathrm{O}_{2}$.

Only one of the airlines can be sampled by an instrument at any given time. The selection of the airline for analysis is made using the multi-position valves, V9 (Valco Instruments Co., model EMT4CSC10MWE) for the $\mathrm{CO}_{2}$ and $\mathrm{O}_{2}$ instrumentation, and $\mathrm{V} 44$ for the $\mathrm{GC}$ (Valco Instruments Co., model EMT2CSC4MWE). Air from the unselected airlines is purged, while air from the selected airlines is sent to the drying system. The purged air flow is maintained using small diaphragm pumps (C4 and C9, KNF Neuberger Inc, model N86) downstream of V9 and V44.

For the $\mathrm{CO}_{2}$ and $\mathrm{O}_{2}$ instrumentation, the selected air flow is drawn through a glass trap, FT1 using a small diaphragm pump (C5, KNF Neuberger Inc, model N05) and is subsequently sent through a second glass trap, FT2 (identical to the first) on the high pressure side of the pump ( $0.7 \mathrm{bar}$ above ambient pressure at P6). Both traps are filled with glass beads (total volume: $\sim 113 \mathrm{~cm}^{3}$, air volume: $\sim 49 \mathrm{~cm}^{3}$ ) and are held at $2^{\circ} \mathrm{C}$ using a refrigerator. The reason for the second trap is because water vapour can be condensed from air at higher pressure more effectively, while the first trap is used to prevent water collecting in the pump. (We chose to use the particular model of pump (N05) for the $\mathrm{CO}_{2}$ and $\mathrm{O}_{2}$ instrumentation because it had been previously tested specifically for $\mathrm{O}_{2}$ and $\mathrm{CO}_{2}$ measurements and was found to have no detectable influence on $\mathrm{O}_{2}$ or $\mathrm{CO}_{2}$ (Manning, 2001). Elsewhere we use the $\mathrm{N} 86$ model since at the time of installation the N05 model was no longer being manufactured). Condensed water is removed from the glass traps (at a flowrate of about $0.2 \mathrm{~mL} / \mathrm{min}$ ) using a peristaltic pump (Cole Parmer, Masterflex, model EW-07542-01), which maintains an air-lock between air inside and outside of the traps. The air is further dried using two stainless steel traps in series, which are cooled in a bath (filled with a heat transfer liquid, Syltherm ${ }^{\mathrm{TM}}$ ) to $-80^{\circ} \mathrm{C}$ using a cryogenic cooler (FTS Systems, model VT490D). (The first of these traps, CT1 is filled with glass beads and has a total volume of $\sim 125 \mathrm{~cm}^{3}$ and an air volume when filled of $\sim 54 \mathrm{~cm}^{3}$. The trap second, CT2 has a much smaller volume, $\sim 13 \mathrm{~cm}^{3}$ and has no glass beads. The gas standards (although already dry to $\sim-60^{\circ} \mathrm{C}$ 


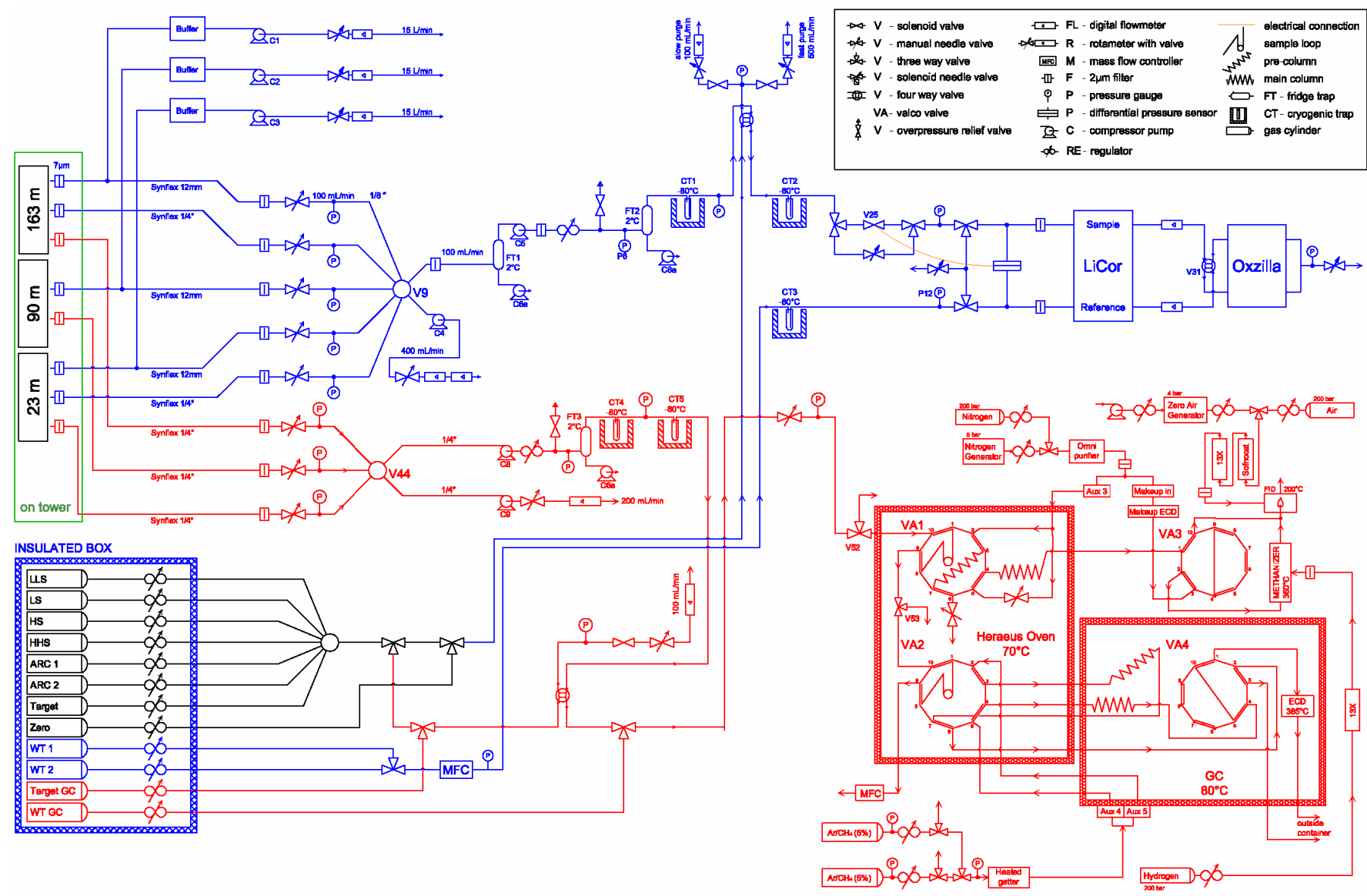

Fig. 2. Schematic of the Ochsenkopf measurement system.

dew point) also pass through this second trap so that the same humidity in the standard gas and in sampled air is achieved, thereby reducing any bias between the two).

For the GC, the air is dried in a similar way to that used for the $\mathrm{CO}_{2}$ and $\mathrm{O}_{2}$ measurements. The main difference is that we use a KNF pump model N86 to draw the selected air flow and the air is not dried upstream of this pump (this is simply due to the fact that there was not enough space for an additional trap in the refrigerator and, so far, no problems of water condensing in this pump have arisen).

\section{$2.2 \mathrm{CO}_{2}$ and $\mathrm{O}_{2}$ analysis}

The dried air is analysed for its $\mathrm{CO}_{2}$ and $\mathrm{O}_{2}$ mixing ratios. $\mathrm{CO}_{2}$ is analysed by NDIR (non- dispersive infra-red) absorption spectroscopy, using a LiCor instrument (model LI-6262) and $\mathrm{O}_{2}$ is analysed by electrochemical reaction using an Oxzilla instrument (model FC-II, Sable Systems Inc.). The two instruments are placed in series and share a common pressure and flow control system (see Fig. 2). Both measurements are made differentially, that is, the mixing ratios are measured relative to a reference gas that is continuously flushing reference cells of each instrument (this reference gas is referred to as the Working Tank (WT) gas and is supplied from an aluminium cylinder of dry, compressed air). The WT gas flow-rate is maintained at $100 \mathrm{~mL} / \mathrm{min}$ using a mass-flow controller (MKS, model 1179B) and is at a pressure of about 100 mbar above ambient at P12 (see Fig. 2). The pressure difference between the sample air (in the sample line) and the WT gas (in the reference line) is measured using a pressure transducer (MKS Instruments Inc., model Baratron 223B, 10 mbar full-scale), the signal from which is used to control the sample line pressure using a proportional valve (V25, MKS, model 248A). With this set-up, the pressure difference is controlled to within \pm 0.025 mbar over an interval of several hours. To protect the pressure transducer from pressure differences of greater than 20 mbar, which may damage it, a 3-way valve was installed immediately upstream, in each of the sample and reference lines, which switches to bypass the transducer when the pressure difference crosses above a threshold value. In addition, there are two 3-way valves to bypass the proportional valve (V25) so that a flow through the sample line can be maintained (in the case of an over pressure on the sample line the proportional valve will close completely). 
The Oxzilla instrument contains two fuel cells; one is used as the reference cell and the other as the sample cell. The dry air mixing ratio of $\mathrm{O}_{2}$ is measured by means of the electrochemical reaction of $\mathrm{O}_{2}$ with a lead anode inside each of the cells. In the reaction, lead is oxidised to lead-oxide at the anode, and $\mathrm{O}_{2}$ is reduced to $\mathrm{H}_{2} \mathrm{O}$ at the cathode. The reaction produces a current that is proportional to the partial pressure of $\mathrm{O}_{2}$ in the sample air. Because the Oxzilla signal is the difference between the two cells, the influences of changes in ambient temperature and pressure on the cells largely cancel out. However, each fuel cell has unique characteristics, in other words, no two cells respond in exactly the same way. Therefore, to make high precision differential measurements, these individual cell biases need to be accounted for; we do this following the method described in Stephens et al. (2007) and Thompson et al. (2007). This involves switching which cell acts as the reference cell and which acts as the sample cell, at regular intervals (at Ochsenkopf this is every $60 \mathrm{~s}$ ). What is measured then, is the difference in the Oxzilla signals with switching (that is, the difference in the differential signal), so over the switching period $(60 \mathrm{~s})$ it is possible to obtain 1 measurement for $\mathrm{O}_{2}$. The switching is made using a 2-position, 4-way ball valve immediately upstream of the Oxzilla (V31, Swagelok, model SS-43Y-31S).

To make high precision measurements of $\mathrm{O}_{2}$, extra consideration is required in designing the air sampling scheme to avoid artefacts arising from molecular fractionation of $\mathrm{O}_{2}$ relative to $\mathrm{N}_{2}$. Molecular fractionation can result in the following cases: 1) in split flows where pressure and temperature gradients exist across the branches of the split (e.g. at T-junctions) (Manning, 2001), 2) flow through any small orifice, such as a leak, with a diameter less than that of the mean-free path between molecular collisions (Dushman, 1962; Keeling et al., 1998), and 3) in high pressure cylinders due to thermal gradients as well as gravimetric settling (Keeling et al., 2007). These effects on $\mathrm{O}_{2}$ measurements are discussed in more detail in the following papers: (Keeling et al., 1998, 2007; Langenfelds et al., 2005).

At Ochsenkopf, we have taken the following steps to minimise fractionation effects as much as possible. First, we minimized the number of T-junctions in the airlines to the $\mathrm{O}_{2}$ instrument, since any temperature or pressure gradients across this could lead to fractionation. The only T-junction used is upstream of the diaphragm pumps where the smaller flow $(100 \mathrm{~mL} / \mathrm{min})$ is drawn from the larger flow $(15 \mathrm{~L} / \mathrm{min})$. The influence of pressure fluctuations at the T-junction from the pumps was minimized by using $10 \mathrm{~m}$ of coiled tubing $\left(\frac{1}{4}{ }^{\prime \prime}\right.$ OD Synflex) between the T-junction and the pump to dampen the pressure pulsations. Furthermore, to test for possible artefacts arising from this T-junction, we installed an extra airline from $23 \mathrm{~m}$ on the tower ( $\frac{1}{4}^{\prime \prime}$ OD Synflex) that is flushed at $100 \mathrm{~mL} / \mathrm{min}$ and contains no T-junctions. Second, care was taken to avoid materials which adsorb or are permeable to $\mathrm{O}_{2}$; this includes the choice of seals used in valves and pressure regulators, as well as the diaphragm of the pump in the $\mathrm{CO}_{2}$ and $\mathrm{O}_{2}$ system airline. Where possible, PCTFE was used for seals as this has been shown to have minimal effect on $\mathrm{O}_{2}$ and where this was not possible, Viton was used, although this has been shown to be semi-permeable to $\mathrm{O}_{2}$ (Rothe et al., 2005; Sturm et al., 2004). The Oxzilla instrument was also modified by removing the internal plastic tubing and filters, which were replaced with stainless steel. In addition, the plastic manifold in the Oxzilla, that holds the two cells, was replaced by a custom built aluminium one. One further important feature of the Ochsenkopf system is the handling of calibration cylinders. Because of the potential for fractionation occurring in the compressed air inside the cylinders, from thermal gradients as well as from gravimetric settling (Keeling et al., 2007), the calibration and WT cylinders were kept horizontally in a thermally insulated box.

The LiCor and Oxzilla instruments are calibrated daily using a suite of four gas standards, spanning the expected range of ambient concentrations at Ochsenkopf, which were prepared at the MPI-BGC. The gas standards were measured for $\mathrm{CO}_{2}$ on the NOAA X2007 scale and for $\mathrm{O}_{2}$ on the Scripps Institution of Oceanography (SIO) scale, which are locally implemented at MPI-BGC, and are used to propagate these scales to Ochsenkopf. The LiCor has a non-linear response to $\mathrm{CO}_{2}$ that is defined using a second-order polynomial fit and is calibrated over the range 340 to $480 \mathrm{ppm}$. The Oxzilla has a linear response to $\mathrm{O}_{2}$ and is calibrated over the range -900 to -60 per meg. The $\mathrm{O}_{2}$ scale is a relative one, on which $\mathrm{O}_{2}$ is expressed as the change in the $\mathrm{O}_{2}$ to $\mathrm{N}_{2}$ ratio relative to a reference $\mathrm{O}_{2}$ to $\mathrm{N}_{2}$ ratio, written as $\delta\left(\mathrm{O}_{2} / \mathrm{N}_{2}\right)$ and has units of "per meg" (for a thorough explanation of this scale see Keeling et al., 1998; Manning and Keeling, 2006). The conversion of $\mathrm{O}_{2}$ mixing ratio (ppm), as measured by the Oxzilla, to "per meg" units is achieved by:

$\delta\left(\mathrm{O}_{2} / \mathrm{N}_{2}\right)=\frac{\delta \mathrm{O}_{2}+\left(\left[\mathrm{CO}_{2}\right]-363.29\right) \times X_{\mathrm{O}_{2}}}{\left(1-X_{\mathrm{O}_{2}}\right) X_{\mathrm{O}_{2}}}$

where $\delta \mathrm{O}_{2}$ is the $\mathrm{O}_{2}$ mixing ratio as measured by the Oxzilla, relative to an arbitrary "zero" defined in the SIO calibration scale. $X_{\mathrm{O}_{2}}$ is the standard mole fraction of $\mathrm{O}_{2}$ in air $\left(X_{\mathrm{O}_{2}}=0.20946\right.$; Machta and Hughes, 1970$)$ and $\left(\left[\mathrm{CO}_{2}\right]-\right.$ 363.29) is the $\mathrm{CO}_{2}$ mixing ratio (ppm) in the sample gas minus an arbitrary reference implicit in the SIO scale and is used to correct for the relative amount of $\mathrm{CO}_{2}$ dilution (Keeling et al., 1998; Kozlova et al., 2008).

The LiCor instrument's baseline response drifts considerably on hourly time-scales. Therefore, we measure a gas standard, referred to as the Zero gas (with ambient concentrations of $\mathrm{CO}_{2}$ and $\mathrm{O}_{2}$ ), every $3 \mathrm{~h}$ to make a 1-point calibration that is used to correct for the LiCor instrument's baseline drift in between daily calibrations. Because the Zero gas is also measured by the Oxzilla, we use this measurement as a check on the Oxzilla baseline as well (however, we have found that it is not necessary to correct for the drift in the Oxzilla instrument's baseline between calibrations). In addition to the 
calibration gases, we measure another gas, referred to as the Target Tank (TT) gas, which is not used in the calibration of the instruments but as an independent quality check on the measurements. The TT gas and the calibration measurements are made every $25 \mathrm{~h}$ so that they are not always occurring at the same time of day to avoid potential biases resulting from diurnal cycles in temperature.

\section{3 $\mathrm{CH}_{4}, \mathrm{CO}, \mathrm{N}_{2} \mathrm{O}$ and $\mathrm{SF}_{6}$ analysis}

We use a GC (Agilent 6890) equipped with a Flame Ionisation Detector (FID) for the measurements of $\mathrm{CH}_{4}$ and $\mathrm{CO}$, and an Electron Capture Detector (ECD) for the measurements of $\mathrm{N}_{2} \mathrm{O}$ and $\mathrm{SF}_{6}$. The GC set-up follows that developed by Worthy et al. (2003) with further modifications by Popa (2008) and Kozlova et al. (2008).

For the measurements of $\mathrm{CH}_{4}$ and $\mathrm{CO}$, we flush a sample loop $(15 \mathrm{~mL})$ with air (either sample or WT GC gas) at $100 \mathrm{~mL} / \mathrm{min}$ for $1.0 \mathrm{~min}$. The air in the sample loop is then allowed to reach ambient pressure by switching the 3-way valve, V52 (Numatics, model HSM3M7H20V), and releasing some of the sample air. At $1.2 \mathrm{~min}$ into the GC run, the sample is transferred to the pre-column (Alltech, molecular sieve 5A, 4ft, ${ }^{1} / /_{8}^{\prime \prime} \mathrm{OD}, 80-100$ mesh) and main column (Alltech, unibeads $1 \mathrm{~S}, 4 \mathrm{ft},{ }^{1} /_{8}^{\prime \prime} \mathrm{OD}, 60-80 \mathrm{mesh}$ ) by switching a 10-port 2-position valve, VA1 (Valco Instrument Co., model ETMA-C10UWE), which are flushed with pure $\mathrm{N}_{2}$. Both columns are kept at $70^{\circ} \mathrm{C}$ using an isothermal oven (Heraeus, model T6). The sample is then directed to the FID using a second 2-position valve, VA3 (the same model as VA1) for the detection of $\mathrm{CH}_{4}$, which elutes from the main column after approximately $2.5 \mathrm{~min}$. Valve VA3 is then switched at $3.0 \mathrm{~min}$ to re-direct the sample through a methanizer (for the quantitative reduction of $\mathrm{CO}$ to $\mathrm{CH}_{4}$, held at $360^{\circ} \mathrm{C}$ ) before being sent to the FID, with $\mathrm{CO}$ eluting after approximately 3.3 minutes. After $4.5 \mathrm{~min}$, VA1 is switched back to begin flushing the sample loop with the next sample and to flush the pre-column and main column with pure $\mathrm{N}_{2}$. The whole run lasts $8 \mathrm{~min}$. The FID flame is fueled with a mixture of $\mathrm{H}_{2}(60 \mathrm{~mL} / \mathrm{min})$ and zero-air $(320 \mathrm{~mL} / \mathrm{min})$ and is held at $175^{\circ} \mathrm{C} . \mathrm{N}_{2}$ is supplied from a generator (DomnickHunter, model UHPZN1001), with the possibility to switch to a cylinder supply, and is purified using a heated inline purifier (NuPure Corp. model, Omni-100). Zero-air is also supplied from a generator (Parker-Balston, model 75-83), again with the possibility to switch to a cylinder supply, and is purified using two cartridges in series (Molecular Products, Sofnocat-423 and Köstrolith, molecular sieve $13 \mathrm{X}$ ). $\mathrm{H}_{2}$ is supplied from a cylinder and is purified using a molecular sieve (Köstrolith, 13X).

Similarly, the measurement of $\mathrm{N}_{2} \mathrm{O}$ and $\mathrm{SF}_{6}$ begins with flushing a sample loop $(25 \mathrm{~mL})$ at $100 \mathrm{~mL} / \mathrm{min}$ with dry air for $1.0 \mathrm{~min}$, after which the air in the sample loop is allowed to reach ambient pressure by switching the 3-way valve, V53 (the same model as V52). At $1.2 \mathrm{~min}$, the sample is trans- ferred, by switching a 10-port 2-position valve, VA2 (the same model as VA1), to the pre-column (Hayesep Q, $6 \mathrm{ft},{ }^{3} /{ }_{16}^{\prime \prime}$ OD, 80-100 mesh) and main column (Hayesep Q, 12ft, ${ }^{3} /{ }_{16}^{\prime \prime}$ OD, 80-100 mesh) which are kept at $80^{\circ} \mathrm{C}$ using the GC's isothermal oven. Both columns are flushed with a mixture of $\mathrm{CH}_{4}(5 \%)$ in Argon. Also at $1.2 \mathrm{~min}$, a second 2-position valve, VA4 (same model as VA1) directs $\mathrm{Ar}-\mathrm{CH}_{4}$ to the ECD while the $\mathrm{O}_{2}$ is eluted from the column, in order to protect the ECD, which would be degraded if exposed to $\mathrm{O}_{2}$. After $4.0 \mathrm{~min}$, VA4 is switched to direct the sample to the ECD for the measurement of $\mathrm{N}_{2} \mathrm{O}$ and $\mathrm{SF}_{6}$ at 5.1 and $6.1 \mathrm{~min}$, respectively. At $4.5 \mathrm{~min}$ into the run, $\mathrm{V} 2$ is switched back to begin back-flushing the pre-column with $\mathrm{Ar}-\mathrm{CH}_{4}$. The ECD is held at $385^{\circ} \mathrm{C}$ and continuously supplied with a gas flow to protect it from damage. Ar- $\mathrm{CH}_{4}$ is supplied from a cylinder (grades 5.5/4.5) and is further purified using an inline purifier (Sigma-Aldrich, model 22-396).

The GC is calibrated on a weekly basis using the same suite of four calibration gases used for $\mathrm{CO}_{2}$ and $\mathrm{O}_{2}$. For $\mathrm{CH}_{4}, \mathrm{CO}$ and $\mathrm{SF}_{6}$, the detectors' response is linear, however, for $\mathrm{N}_{2} \mathrm{O}$ the response is described by a second-order polynomial. We calculate the mixing ratio of each gas species using the peak area. Each sample run by the GC is interspersed with a reference gas (referred to as Working Tank GC (WT-GC) gas) measurement. The WT-GC gas is used to correct for short-term drift in the instrument's response due to changes in ambient temperature and pressure. Similar to the $\mathrm{CO}_{2}$ and $\mathrm{O}_{2}$ system, a GC Target Tank (TT-GC) gas is also measured daily as an independent check on the measurements. The scales used are the NOAA04 scale for $\mathrm{CH}_{4}$, the NOAA2006 scale for $\mathrm{N}_{2} \mathrm{O}$, the NOAA2000 scale for $\mathrm{CO}$ and the NOAA2006 scale for $\mathrm{SF}_{6}$, which are implemented at MPI-BGC, via primary standards from NOAA, and are propagated to Ochsenkopf.

Using the instrumental set-up described, we achieve the following instrumental precisions and accuracies (see Table 1). For $\mathrm{CO}_{2}$ and $\mathrm{O}_{2}$, the precisions are given by the $1-\sigma$ standard deviation for 6 min of TT gas measurement (made daily), averaged over 2.5 years. For the GC gases, the precisions are given by the absolute differences of the two consecutive TT gas measurements (made daily), averaged over 2.5 years. The accuracies of all gases are given by the absolute difference (over 2.5 years) of the TT gas measurement and the MPI-BGC assigned mixing ratios in the TT gas. Also shown in Table 1 is the standard deviation (over 2.5 years) of the differences between the TT gas measurement and the MPI-BGC value.

Air is sampled from all three heights routinely in a 3-h cycle, that is, $1 \mathrm{~h}$ for each height. The $\mathrm{CO}_{2}$ and $\mathrm{O}_{2}$ data are recorded at a frequency of $2 \mathrm{~min}$; at the start of sampling a new height, the first $1 \mathrm{~min}$ is used to purge the air line, so over $1 \mathrm{~h}, 29$ data points are collected. The gases measured by the GC are recorded at a frequency of $16 \mathrm{~min}$, so over $1 \mathrm{~h}$, 3 or 4 measurements are collected, alternately. 
Table 1. Precisions and accuracies of gas species.

\begin{tabular}{llll}
\hline Species & Precision & Accuracy & SD of difference \\
\hline $\mathrm{CO}_{2}$ & $\pm 0.02 \mathrm{ppm}$ & $\pm 0.1 \mathrm{ppm}$ & $0.08 \mathrm{ppm}$ \\
$\delta\left(\mathrm{O}_{2} / \mathrm{N}_{2}\right)$ & \pm 4.0 per meg & \pm 6.0 per meg & 13.6 per meg \\
$\mathrm{CH}_{4}$ & $\pm 1.3 \mathrm{ppb}$ & $\pm 1.8 \mathrm{ppb}$ & $1.8 \mathrm{ppb}$ \\
$\mathrm{CO}$ & $\pm 1.2 \mathrm{ppb}$ & $\pm 1.9 \mathrm{ppb}$ & $2.1 \mathrm{ppb}$ \\
$\mathrm{N}_{2} \mathrm{O}$ & $\pm 0.18 \mathrm{ppb}$ & $\pm 0.5 \mathrm{ppb}$ & $0.6 \mathrm{ppb}$ \\
$\mathrm{SF}_{6}$ & $\pm 0.08 \mathrm{ppt}$ & $\pm 0.13 \mathrm{ppt}$ & $0.32 \mathrm{ppt}$ \\
\hline
\end{tabular}

\subsection{Supporting measurements and automation}

Air for flask samples at Ochsenkopf is drawn from the $163 \mathrm{~m}$ level through a dedicated line (12 mm OD Synflex) using a diaphragm pump (KNF Neuberger, N828). This line is flushed for at least $30 \mathrm{~min}$ at $15 \mathrm{~L} / \mathrm{min}$ before flask samples are taken. To fill the flasks, the N828 pump is bypassed and another diaphragm pump (KNF Neuberger, N010) is used to flush the line to the flasks ( $\frac{1}{4}^{\prime \prime}$ OD Synflex), and the flasks, at $2.5 \mathrm{~L} / \mathrm{min}$ for a minimum of $15 \mathrm{~min}$. Immediately upstream of the flasks, a stainless steel cartridge of anhydrous $\mathrm{Mg}\left(\mathrm{ClO}_{4}\right)_{2}$ is used to dry the air (to approximately $-30^{\circ} \mathrm{C}$ dew point). The pump is separated from the drying cartridge by approximately $1.5 \mathrm{~m}$ of $\frac{1}{4}^{\prime \prime}$ tubing, which helps to buffer it from pressure fluctuations from the pump. This is an important consideration because pressure changes across $\mathrm{Mg}\left(\mathrm{ClO}_{4}\right)_{2}$ drying traps while filling flasks have been found to influence the $\mathrm{CO}_{2}$ and $\mathrm{N}_{2} \mathrm{O}$ mixing ratios (Langenfelds et al., 2001). The flasks have $1 \mathrm{~L}$ volume and are equipped with two valves, one at each end, which allows them to be connected in a chain for more effective flushing (to connect the flasks we use $\frac{1^{\prime \prime}}{4}$ OD Synflex tubing and Cajon ${ }^{\mathrm{TM}}$ fittings). The flasks are filled in triplets (to 0.8 bar gauge) to allow statistical analyses on the sampling to be made and in case one flask has a fault. To reduce adsorption and desorption of gas molecules on the inner surface, the flasks are made of borosilicate glass, and to minimize the permeation of gases, the valves are sealed with caps made from PCTFE (Sturm et al., 2004). Furthermore, prior to sample collection, the flasks are prepared by filling them with dry air to the sample pressure $(0.8 \mathrm{bar})$. This preparation reduces pressure changes inside the flask while filling, which is especially important for $\mathrm{O}_{2}$ sampling owing to the potential for significant molecular fractionation effects but also helps maintain an equilibrium of adsorbed molecules on the inside surface of the flask.

Temperature and relative humidity were measured at all three heights; the same types of sensors were used at $23 \mathrm{~m}$ and $90 \mathrm{~m}$; these were a PT100 and a capacitive humidity sensor (both MELA SensorTechnik). More accurate sensors were used at $163 \mathrm{~m}$, namely an aspirated thermometer and a dewpoint mirror (both Meteolabor, model THYGAN VTP6).
Wind speed and direction are measured at $163 \mathrm{~m}$ using a 3$\mathrm{D}$ sonic anemometer (Thies, model 4.3830) and pressure is measured at $90 \mathrm{~m}$ (Vaisala, model PTB101B). Data from all heights is sent via CAN BUS to the container-laboratory.

The complete measuring system was automated using a customised programme written in LabVIEW ${ }^{\mathrm{TM}}$, which provided the interface to the computer hardware (all National Instruments Inc.). The valves were controlled using a digital I/O card (model PCI-DIO-96) and relay boards (model SC206X) and the analogue input signals were connected to a terminal board (SCB-68) sampled using a data acquisition card (PCI-6225). The LabVIEW ${ }^{\mathrm{TM}}$ software was also used for all data processing and recording and for running all sample air and calibration cycles.

\section{Results and discussion}

\subsection{Comparison of in-situ measurements with flask samples}

The flask samples provide an ongoing check on the in-situ measurements. Because the flasks are filled and analysed independently from the in-situ measurement system, an intercomparison can be a useful test for artefacts arising from the air sampling and/or drying system that are not possible to identify from the TT gas measurements (that is, assuming that any artefacts in the flask sample collection and analysis are insignificant compared with those in the in-situ measurements). The filling of flasks and the in-situ measurement from $163 \mathrm{~m}$ do not always exactly correspond in time (since in-situ sampling from $163 \mathrm{~m}$ is made on a 3-hourly cycle). Therefore, for the inter-comparison, only flask and in-situ measurements that were made within $1 \mathrm{~h}$ of each other were used and the in-situ measurement closest in time to the flask sample was chosen. Because the flasks are sampled in triplet, we used the triplet mean for the comparison. The mean absolute differences for all species are close to the accuracies determined from the TT gas measurements (see Table 2). The offsets from the TT gas - determined accuracies may arise from a combination of the following: 1) the different number of samples included in the analysis, especially in the case of $\delta\left(\mathrm{O}_{2} / \mathrm{N}_{2}\right)$ (flask analyses for $\mathrm{O}_{2}$ only began in February 2007, so there are fewer points for this comparison as for the other gas species), 2) the time offset between the flask and in-situ measurement and 3) possible artefacts in the flask collection and analysis. However, on the basis of these results, we do not consider there to be any significant artefacts.

\subsection{Seasonal cycles and multi-annual trends}

Figure $3 \mathrm{a}$ and $\mathrm{b}$ shows the entire record of $\mathrm{CO}_{2}$ and $\mathrm{O}_{2}$ mixing ratios from the $163 \mathrm{~m}$ level at Ochsenkopf as daily trimmed mean values (i.e. the mean excluding the highest and lowest $25 \%$ of the observations for each day). The multi-annual trends and seasonal cycles are represented with 
Table 2. Inter-comparison of flask and in-situ measurements from $163 \mathrm{~m}$. Differences (non-absolute) are in-situ flask.

\begin{tabular}{lrrrr}
\hline & $\begin{array}{r}\text { mean absolute } \\
\text { difference }\end{array}$ & $\begin{array}{r}\text { mean } \\
\text { difference }\end{array}$ & $\begin{array}{r}\text { sd of } \\
\text { difference }\end{array}$ & $\begin{array}{r}\text { number of } \\
\text { samples }\end{array}$ \\
\hline $\mathrm{CO}_{2}(\mathrm{ppm})$ & \pm 0.16 & -0.01 & \pm 0.18 & 74 \\
$\delta\left(\mathrm{O}_{2} / \mathrm{N}_{2}\right)($ per meg) & \pm 3.5 & -0.72 & \pm 5.1 & 30 \\
$\mathrm{CH}_{4}(\mathrm{ppb})$ & \pm 2.15 & 0.21 & \pm 2.86 & 47 \\
$\mathrm{CO}(\mathrm{ppb})$ & \pm 2.31 & 0.76 & \pm 2.74 & 51 \\
$\mathrm{~N}_{2} \mathrm{O}(\mathrm{ppb})$ & \pm 0.47 & -0.23 & \pm 0.57 & 86 \\
$\mathrm{SF}_{6}(\mathrm{ppt})$ & \pm 0.08 & 0.05 & \pm 0.16 & 82 \\
\hline
\end{tabular}

Periods when the in-situ measurements were of poor quality (judged on the basis of the TT results) were excluded from the comparison.

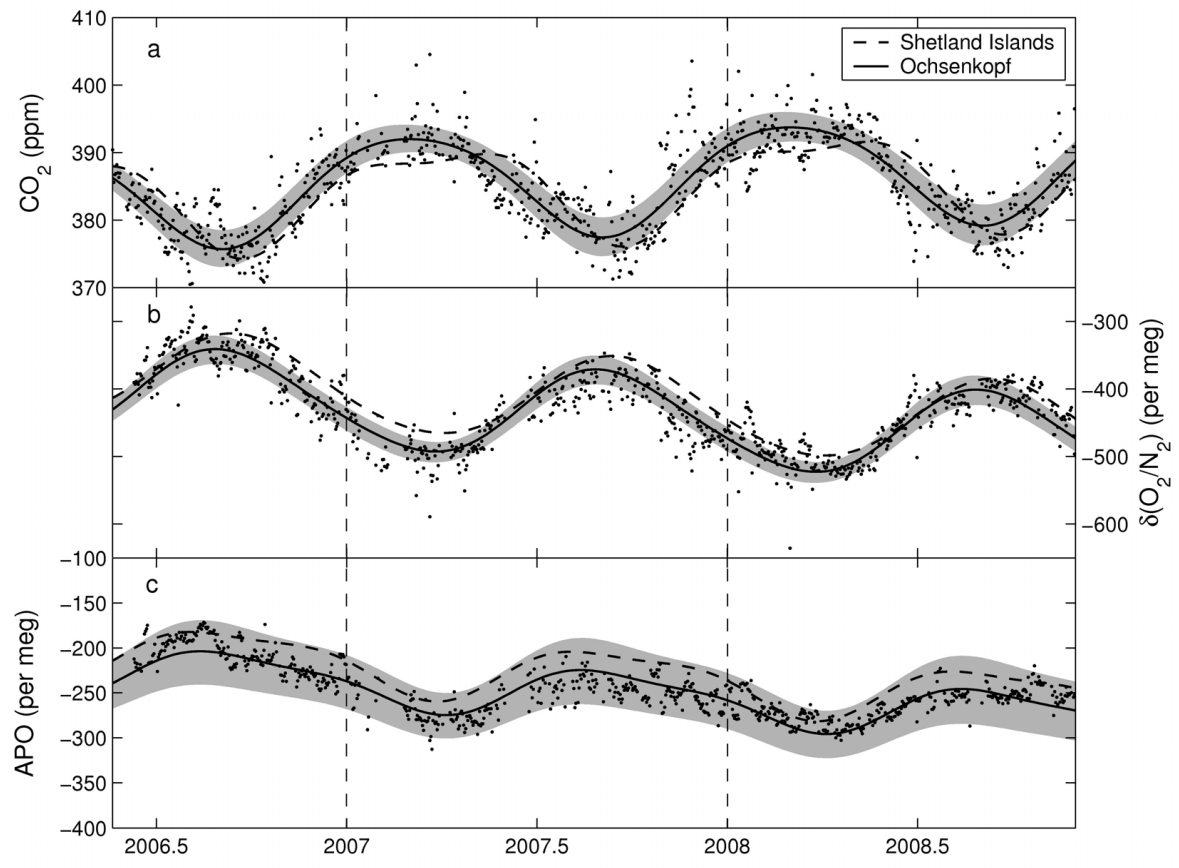

Fig. 3. Two and a half years of (a) $\mathrm{CO}_{2}$, (b) $\mathrm{O}_{2}$ and (c) APO data, from the $163 \mathrm{~m}$ level at Ochsenkopf, shown as daily trimmed mean values (black points). Also shown are the daily standard deviations (grey shaded area), and least squares fitted linear trend plus 4-harmonic curves for Ochsenkopf (solid line) and for the Shetland Islands (dashed line).

linear plus 4-harmonic curves fitted simultaneously to the data. The daily standard deviations of $\mathrm{CO}_{2}$ and $\mathrm{O}_{2}$ are indicated with grey shaded areas, the bounds of which are also given by linear plus 4-harmonic curves fitted to the mean \pm the daily standard deviation. From the approximately 2.5 year record of $\mathrm{CO}_{2}$, the seasonal cycle can clearly be seen (Fig. 3a), with a winter maximum and summer minimum, which in the northern hemisphere is largely driven by terrestrial sources and sinks (e.g. Fung et al., 1987; Keeling et al., 1996). The amplitude and the timing of the maximum and minimum of the seasonal cycles were estimated from the 4-harmonic curve fit, after the multi-annual trend had been subtracted, and are given in Table 3. For comparison, the linear plus 4-harmonic curve fit to $\mathrm{CO}_{2}$ data from flask samples taken at the marine site, Shetland Islands $\left(59^{\circ} 51^{\prime} \mathrm{N}, 1^{\circ} 16^{\prime} \mathrm{W}\right)$ are also shown in Fig. 3a. (The Shetland Islands site is in the flask-sampling network run by the MPI-BGC and measurements from this site are tied to the same calibration scales as those at Ochsenkopf. The flask sampling procedure is also the same as that used at Ochsenkopf and flasks are filled in approximately weekly intervals). $\mathrm{CO}_{2}$ at Ochsenkopf began to rise earlier during the autumn and reached an earlier and higher maximum than at the Shetland Islands. In spring, $\mathrm{CO}_{2}$ also began to decline earlier at Ochsenkopf, however, the minimum was higher than at the Shetland Islands. The earlier onset of $\mathrm{CO}_{2}$ rise and decline at Ochsenkopf are due to the site's closer proximity to the dominant biospheric fluxes, which have a 
Table 3. Properties of seasonal cycles and trends. The numbers in brackets are the days of the secondary maxima and minima.

\begin{tabular}{lrrrrrrr}
\hline & $\begin{array}{r}\mathrm{CO}_{2} \\
(\mathrm{ppm})\end{array}$ & $\begin{array}{r}\delta\left(\mathrm{O}_{2} / \mathrm{N}_{2}\right) \\
(\mathrm{per} \text { meg) }\end{array}$ & $\begin{array}{r}\mathrm{APO} \\
(\text { per meg) }\end{array}$ & $\begin{array}{r}\mathrm{CH}_{4} \\
(\mathrm{ppb})\end{array}$ & $\begin{array}{r}\mathrm{CO} \\
(\mathrm{ppb})\end{array}$ & $\begin{array}{r}\mathrm{N}_{2} \mathrm{O} \\
(\mathrm{ppb})\end{array}$ & $\begin{array}{r}\mathrm{SF}_{6} \\
(\mathrm{ppt})\end{array}$ \\
\hline day of minimum & 247 & 80 & 92 & 218 & 236 & 267 & - \\
& & & & $(28)$ & & $(61)$ & - \\
day of maximum & 25 & 241 & 246 & 115 & 108 & 164 & - \\
& & & & $(314)$ & & $(347)$ & - \\
amplitude & 15.46 & 134.6 & 43.1 & 34.2 & 75.1 & 0.37 & - \\
uncertainty & \pm 1.04 & \pm 6.8 & \pm 3.3 & \pm 6.3 & \pm 6.0 & \pm 0.15 & - \\
trend (per year) & 1.60 & -16.3 & -9.7 & 9.8 & 0.08 & 0.99 & 0.32 \\
uncertainty & \pm 0.47 & \pm 3.1 & \pm 1.5 & \pm 2.8 & \pm 0.7 & \pm 0.07 & \pm 0.02 \\
\hline
\end{tabular}

Because of the sensitivity of the trend estimate to inter-annual variations in the maxima and minima, the trend (for all species except $\mathrm{SF}_{6}$ ) was calculated as the linear component of curves fitted to two complete seasonal cycles (2006.5-2008.5). The SF 6 trend was calculated as the linear regression through all data.

strong seasonal dependence, whereas, the higher maximum and minimum values are due to the closer proximity to anthropogenic emissions that have minimal seasonal variation.

The seasonal cycle of $\mathrm{O}_{2}$ is approximately 6-months outof-phase with the $\mathrm{CO}_{2}$ cycle (Fig. 3b). This is because the strongest seasonal sources and sinks of $\mathrm{CO}_{2}$ are negatively correlated with those of $\mathrm{O}_{2}$, namely, the biosphere fluxes, from photosynthesis and respiration (fluxes from fossil fuel combustion are also negatively correlated with $\mathrm{CO}_{2}$, however, these have only a small seasonal dependence) (e.g. Keeling and Shertz, 1992). The timing of the $\mathrm{O}_{2}$ maximum and minimum, however, is not exactly opposite to $\mathrm{CO}_{2}$ owing to oceanic fluxes, which contribute much more to the $\mathrm{O}_{2}$ than to the $\mathrm{CO}_{2}$ seasonal cycle, because the ocean-atmosphere equilibration time for $\mathrm{CO}_{2}$ is of the order of 1 year compared to several weeks for $\mathrm{O}_{2}$ (Broecker and Peng, 1974). It is also for this reason that the amplitude of the $\mathrm{O}_{2}$ cycle is larger than one would expect from terrestrial biosphere fluxes alone (that is 134.6 per meg instead of $(1.1 \times 15.46) / 0.2095=81.2$ per meg, using a stoichiometric ratio of $\mathrm{O}_{2}$ to $\mathrm{CO}_{2}$ for biosphere fluxes of 1.1, Severinghaus, 1995; and the molar fraction of $\mathrm{O}_{2}$ in air of 0.2095, Machta and Hughes, 1970).

The contribution of oceanic fluxes on the $\mathrm{O}_{2}$ mixing ratio can be estimated by the combination of $\mathrm{CO}_{2}$ and $\mathrm{O}_{2}$ measurements into a tracer known as Atmospheric Potential Oxygen (APO). APO is conservative with respect to terrestrial biosphere fluxes and, on time-scales in the order of one year, primarily reflects ocean fluxes of $\mathrm{O}_{2}$ and atmospheric transport (Stephens et al., 1998). APO is shown in Fig. 3c and was calculated according to:

$\mathrm{APO}=\delta\left(\mathrm{O}_{2} / \mathrm{N}_{2}\right)-r\left(\mathrm{CO}_{2}-C_{\mathrm{ref}}\right) / X_{\mathrm{O}_{2}}$

where $r$ is the stoichiometric ratio of $\mathrm{O}_{2}$ to $\mathrm{CO}_{2}$ for biosphere fluxes, $X_{\mathrm{O}_{2}}$ is the molar fraction of $\mathrm{O}_{2}$ in air, and $C_{\text {ref }}$ is an arbitrary reference $\mathrm{CO}_{2}$ mixing ratio (we use $C_{\text {ref }}=350$ ) implicit to the APO "per meg" scale (Stephens et al., 1998).
The amplitude of the APO seasonal cycle, 43.1 per meg, plus the amplitude of the $\mathrm{O}_{2}$ seasonal cycle expected from terrestrial biosphere fluxes, gives $124.3 \pm 10.1$ per meg, which is close to the $\mathrm{O}_{2}$ amplitude observed. However, because of a phase shift between the two cycles, it is not expected that their sum will be exactly that of the observed $\mathrm{O}_{2}$ amplitude. At Ochsenkopf, the APO maxima and minima occur later than at the Shetland Islands (see Fig. 3c), owing to the transport time of the largely oceanic signal to the interior of the continent (Kozlova et al., 2008).

The multi-annual trends of $\mathrm{CO}_{2}$ and $\mathrm{O}_{2}$ were taken as the linear components of the linear plus 4-harmonic curves fitted to the data (see Table 3). Because the trend is only in the order of one tenth of the seasonal amplitude, it is very sensitive to inter-annual variations in the maxima and minima in the short (2.5 years) record. To minimise the influence of these variations, we used the linear component of curves fitted to two complete seasonal cycles (2006.5-2008.5) for the estimate of the multi-annual trend. Even so, the associated uncertainties are large; therefore, it is not possible to draw any strong conclusions from the observed trends in this short record.

The records of the trace gases $\mathrm{CH}_{4}, \mathrm{CO}, \mathrm{N}_{2} \mathrm{O}$ and $\mathrm{SF}_{6}$ from the $163 \mathrm{~m}$ level at Ochsenkopf are shown in Fig. 4 also as daily trimmed mean values. For $\mathrm{CH}_{4}, \mathrm{CO}$ and $\mathrm{N}_{2} \mathrm{O}$ the multi-annual trends and seasonal cycles were represented by linear plus 4-harmonic curves fitted (using least-squares) to the data (in the same way as for $\mathrm{CO}_{2}$ and $\mathrm{O}_{2}$ ). In the $\mathrm{SF}_{6}$ record, however, there is no seasonality but the multi-annual trend could be well approximated using a linear fit.

At Ochsenkopf, the seasonal cycle of $\mathrm{CH}_{4}$ exhibits a double maximum, in April and November, with a minimum in August (see Fig. 4a). Similarly shaped $\mathrm{CH}_{4}$ seasonal cycles are seen elsewhere in the northern hemisphere, e.g. at Cold Bay $\left(55^{\circ} 12^{\prime} \mathrm{N}, 162^{\circ} 43^{\prime} \mathrm{W}\right)$ (Dlugokencky et al., 1994) and Fraserdale $\left(49^{\circ} 53^{\prime} \mathrm{N}, 81^{\circ} 34^{\prime} \mathrm{W}\right)$ (Worthy et al., 1998) and largely result from the combined influences of natural 


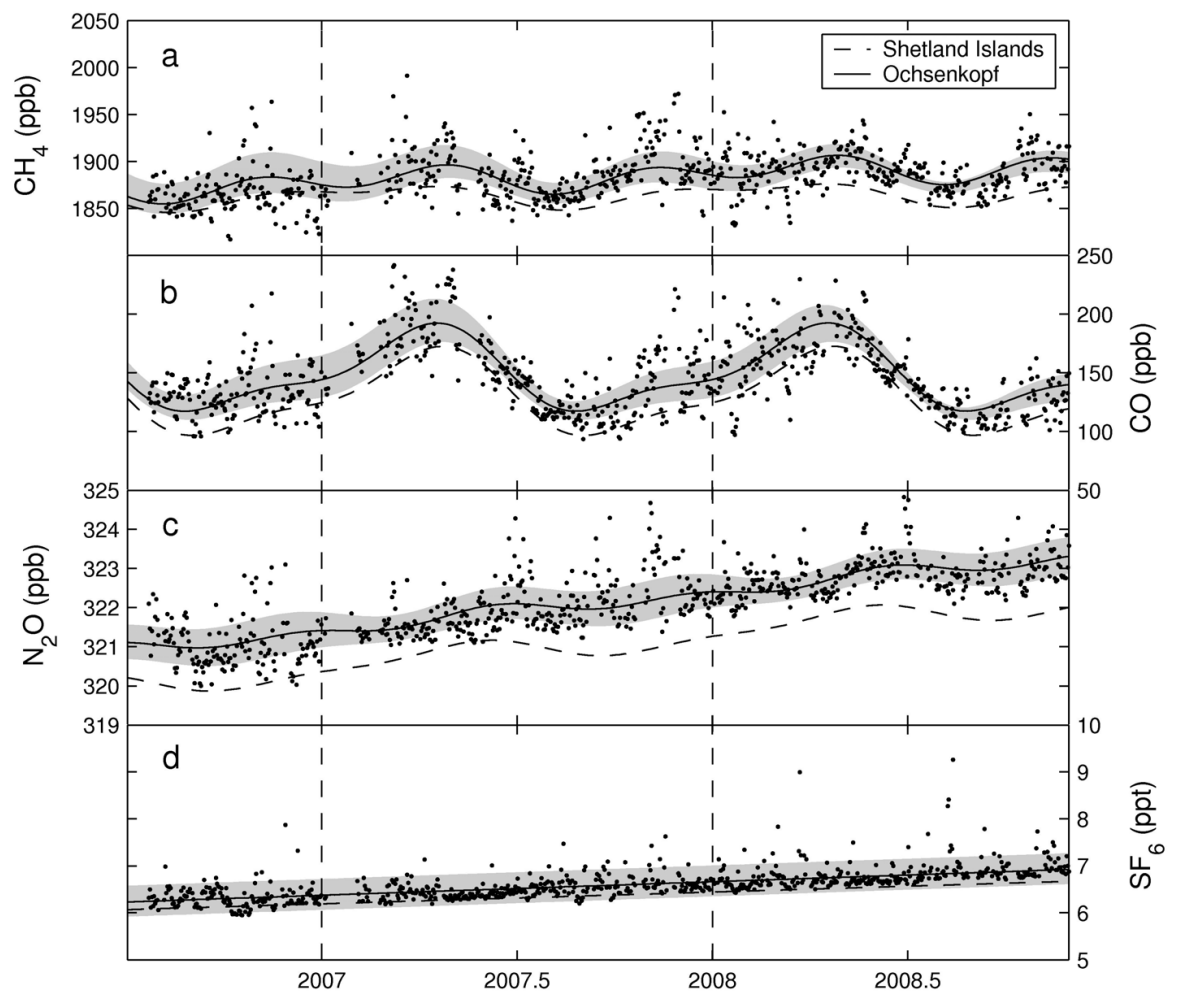

Fig. 4. Two and a half years of (a) $\mathrm{CH}_{4}$, (b) $\mathrm{CO}$, (c) $\mathrm{N}_{2} \mathrm{O}$ and (d) $\mathrm{SF}_{6}$ data from Ochsenkopf at 163 m shown as daily trimmed mean values (black points). Also shown are the daily standard deviations (grey shaded area), and least-squares fitted linear trends plus 4-harmonic curves for $\mathrm{CH}_{4}, \mathrm{CO}$ and $\mathrm{N}_{2} \mathrm{O}$ (solid line) and for the Shetland Islands (dashed line). For $\mathrm{SF}_{6}$ the least-squares fit is linear only and is shown for Ochsenkopf (solid line) and the Shetland Islands (dashed line).

emissions, such as from wetlands, and the variability of the principal sink, that is through oxidation in the troposphere by the OH radical (Bousquet et al., 2006; Logan et al., 1981). However, the cause of the late autumn maximum is unclear. Recently, Mastepanov et al. (2008) proposed that a release of $\mathrm{CH}_{4}$ from tundra in the high northern latitudes, brought about by the onset of soil freezing, could explain this autumn increase. Although Ochsenkopf lies at $50^{\circ} 02^{\prime} \mathrm{N}$, transport of $\mathrm{CH}_{4}$ from high northern latitudes is possible, in which case a lag of several days between the peak emissions and the observed maximum would be expected. The Ochsenkopf maximum, in early November, is consistent with such a delay but without further investigation we cannot draw any strong conclusions about its cause. Other factors may also contribute to the late autumn $\mathrm{CH}_{4}$ increase at Ochsenkopf, such as emissions from agricultural burn-offs in eastern Europe and changes in atmospheric transport. Furthermore, at the Shetland Islands, an autumn maximum, although visible, is not as prominent, suggesting that the tundra emissions alone are not sufficient to explain the Ochsenkopf maximum.
$\mathrm{CH}_{4}$ mixing ratios are consistently higher at Ochsenkopf compared with the Shetland Islands owing to the proximity of natural and anthropogenic sources which are stronger over the continent. Over two complete seasonal cycles (2006.5-2008.5), we calculated an average increase in $\mathrm{CH}_{4}$ of $9.8 \pm 2.8 \mathrm{ppb} / \mathrm{yr}$, which within the uncertainty range is the same as that observed at the Shetland Islands $(10.4 \pm 2.9 \mathrm{ppb} / \mathrm{yr})$ for the same time period. This rate of increase is significantly higher than the global mean from 1999 until the end of 2006, which was close to zero (Forster et al., 2007). Since the beginning of 2007, there has been a renewed increase in the global $\mathrm{CH}_{4}$ growth-rate of about $6 \mathrm{ppb} / \mathrm{yr}$ (Rigby et al., 2008). Rigby et al. (2008) suggest that this change may be the result of a small decrease in $\mathrm{OH}$ levels between 2006 and 2007, combined with an increase in $\mathrm{CH}_{4}$ emissions, particularly in the northern hemisphere.

The seasonal cycle of $\mathrm{CO}$ shows a maximum in April and minimum in August and is similar in shape, phase and amplitude to that at the Shetland Islands site (see Fig. 4b). However, $\mathrm{CO}$, like $\mathrm{CH}_{4}$, is elevated at Ochsenkopf with respect to the marine boundary layer (as represented by the Shetland Islands record) owing to the fact that $\mathrm{CO}$ sources, for example fossil fuel combustion, are strongest over the continent. 
The seasonal variation is determined by a combination of atmospheric transport and mixing as well as by the seasonality of the $\mathrm{OH}$ radical, which accounts for more than $90 \%$ of the CO sink (Logan et al., 1981). There appears to be negligible trend in $\mathrm{CO}$, but inter-annual variability has been observed elsewhere owing to variations in emissions, for example from biomass burning (Langenfelds et al., 2002).

The $\mathrm{N}_{2} \mathrm{O}$ seasonal cycle at Ochsenkopf shows a double maximum, in June and December and minimum, in March and September (see Fig. 4c). In contrast, the $\mathrm{N}_{2} \mathrm{O}$ cycle at the Shetland Islands site shows a single maximum in May and minimum in October. At continental sites, the $\mathrm{N}_{2} \mathrm{O}$ seasonality is modulated by atmospheric transport, soil emissions, ocean fluxes and the mixing of tropospheric air with $\mathrm{N}_{2} \mathrm{O}$-poor stratospheric air. Because these processes occur with differing phases, the result is a weaker and more complex seasonal cycle at continental sites (Jiang et al., 2007; Levin et al., 2002; Liao et al., 2004; Nevison et al., 2004). $\mathrm{N}_{2} \mathrm{O}$ is increasing steadily in the atmosphere owing to enhanced emissions from human activities, mostly from agriculture. At Ochsenkopf, the average growth-rate over the period 2006.5-2008.5 was $0.99 \pm 0.07 \mathrm{ppb} / \mathrm{yr}$ and was, within the uncertainty bounds, the same as that seen at the Shetland Islands $(0.95 \pm 0.04 \mathrm{ppb} / \mathrm{yr})$ and is consistent with the global mean growth rate of $0.8 \mathrm{ppb} / \mathrm{yr}$ (Forster et al., 2007). In Fig. $4 c$, elevated $\mathrm{N}_{2} \mathrm{O}$ mixing ratios are seen at Ochsenkopf relative to the Shetland Islands. From the comparison of insitu and flask measurements (see Sect. 3.1), we can exclude the possibility of this offset being caused by a measurement bias, because flask samples from Ochsenkopf and the Shetland Islands are collected using the same type of sampler and are subject to the same analysis in the MPI-BGC laboratory. The higher $\mathrm{N}_{2} \mathrm{O}$ at Ochsenkopf is due to the site's closer proximity to the strongest sources, that is, from microbial nitrification and denitrification in soils.

$\mathrm{SF}_{6}$ is a very long-lived trace gas (a lifetime of 3200 years) with only anthropogenic sources (Forster et al., 2007). For this reason, and because the emissions do not vary significantly on a seasonal time-scale, there is no seasonal cycle in $\mathrm{SF}_{6}$. However, the $\mathrm{SF}_{6}$ mixing ratio is rising owing to steady emissions and during the 2.5 year record at Ochsenkopf, $\mathrm{SF}_{6}$ rose on average $0.32 \pm 0.02 \mathrm{ppt} / \mathrm{yr}$ (see Fig. $4 \mathrm{~d}$ ). Because the sources of $\mathrm{SF}_{6}$ (mainly industrial) are on land, the mixing ratio at Ochsenkopf is elevated with respect to that in the marine boundary layer (by a mean of $0.21 \mathrm{ppt}$ ).

\subsection{Diurnal cycles}

Figure 5 shows a typical example of the diurnal variation in mixing ratio of all the gas species, as well as potential temperature, measured at Ochsenkopf at 163, 90 and $23 \mathrm{~m}$ on the tower from 11 to 14 May 2008. The data shown are hourly averages and because the heights are sampled on a 3-hourly cycle (see Sect. 2.3) the data for each height are at 3-hourly intervals. At night, the air at the surface cools, as seen in the lower potential temperature at $23 \mathrm{~m}$ (Fig. $5 \mathrm{~g}$ ), and stable conditions develop. The air at $23 \mathrm{~m}$ is within the nocturnal boundary layer and there is a build-up of $\mathrm{CO}_{2}$ and draw-down of $\mathrm{O}_{2}$ due to respiration fluxes. In contrast, there are only very small changes in the $\mathrm{CO}_{2}$ and $\mathrm{O}_{2}$ mixing ratios at $90 \mathrm{~m}$ and $163 \mathrm{~m}$ as these heights are above the nocturnal boundary layer and are in the residual layer, which contains well mixed air that was last in contact with the surface on the previous day. During the day, the surface air warms and convective mixing occurs, removing the vertical gradient that had developed over night. In addition, there is a small drawdown in $\mathrm{CO}_{2}$ and increase in $\mathrm{O}_{2}$, seen at all heights, from the photosynthesis fluxes.

Most often no diurnal variation was observed for $\mathrm{CH}_{4}$, $\mathrm{N}_{2} \mathrm{O}, \mathrm{CO}$ and $\mathrm{SF}_{6}$, that is, there was no significant accumulation of these gases in the nocturnal boundary. This is due to the fact that 1) the fluxes of these gases in the vicinity of the tower are very small, so there is no accumulation in the nocturnal boundary layer locally, and 2) there is very little or no diurnal cycle in their fluxes. Therefore, the mixing ratio within the nocturnal boundary layer stays more or less the same as that in the residual layer above. Hence, it is also unusual to see the development of a vertical gradient, even during stable conditions. On the night of 13 May, however, such a gradient did develop, particularly noticeable in $\mathrm{CO}$, and suggests that there were nearby emissions of these gases at this time.

Because Ochsenkopf tall tower is situated on a peak (in the Fichtelgebirge range) the air flow is also modulated by the mountain-valley terrain. The sloping terrain can affect the development of the nocturnal boundary layer, for instance by the subsidence of cool air at the surface, creating downslope winds, and can also influence the day-time surface layer by up-slope winds. As diurnal cycles in trace gases are very much influenced by atmospheric mixing, the mountainvalley meteorology can also have an affect on these. An example of the effect of subsidence, from 21 to 24 September 2006, is shown in Fig. 6. During the nights shown, the air at the surface cooled down much more than the air above and began to subside, allowing the entrainment of air from above. Notably, there was an increase in wind speed (at $163 \mathrm{~m}$ ) during the transition from stable to unstable, and unstable to stable, conditions.

The effect of entraining air can be seen in the decrease in mixing ratios of the trace gases, $\mathrm{CH}_{4}, \mathrm{CO}, \mathrm{N}_{2} \mathrm{O}$ and $\mathrm{SF}_{6}$ at 163 and $90 \mathrm{~m}$ (in Fig. 6 only $\mathrm{CH}_{4}$ is shown). For $\mathrm{CH}_{4}$, the night-time mixing ratio was about $50 \mathrm{ppb}$ below that of the day-time well mixed PBL, suggesting that this air was in fact from the free-troposphere. At $23 \mathrm{~m}$, the night-time mixing ratio remained approximately the same as during the preceding day, as it was within the surface layer and appears not to be influenced by entraining air. In the case of $\mathrm{CO}_{2}$, there was a night-time increase at $23 \mathrm{~m}$, owing to respiration fluxes, whereas at 90 and $163 \mathrm{~m}$ the mixing ratio was only slightly higher than that during the day, when photosynthetic 


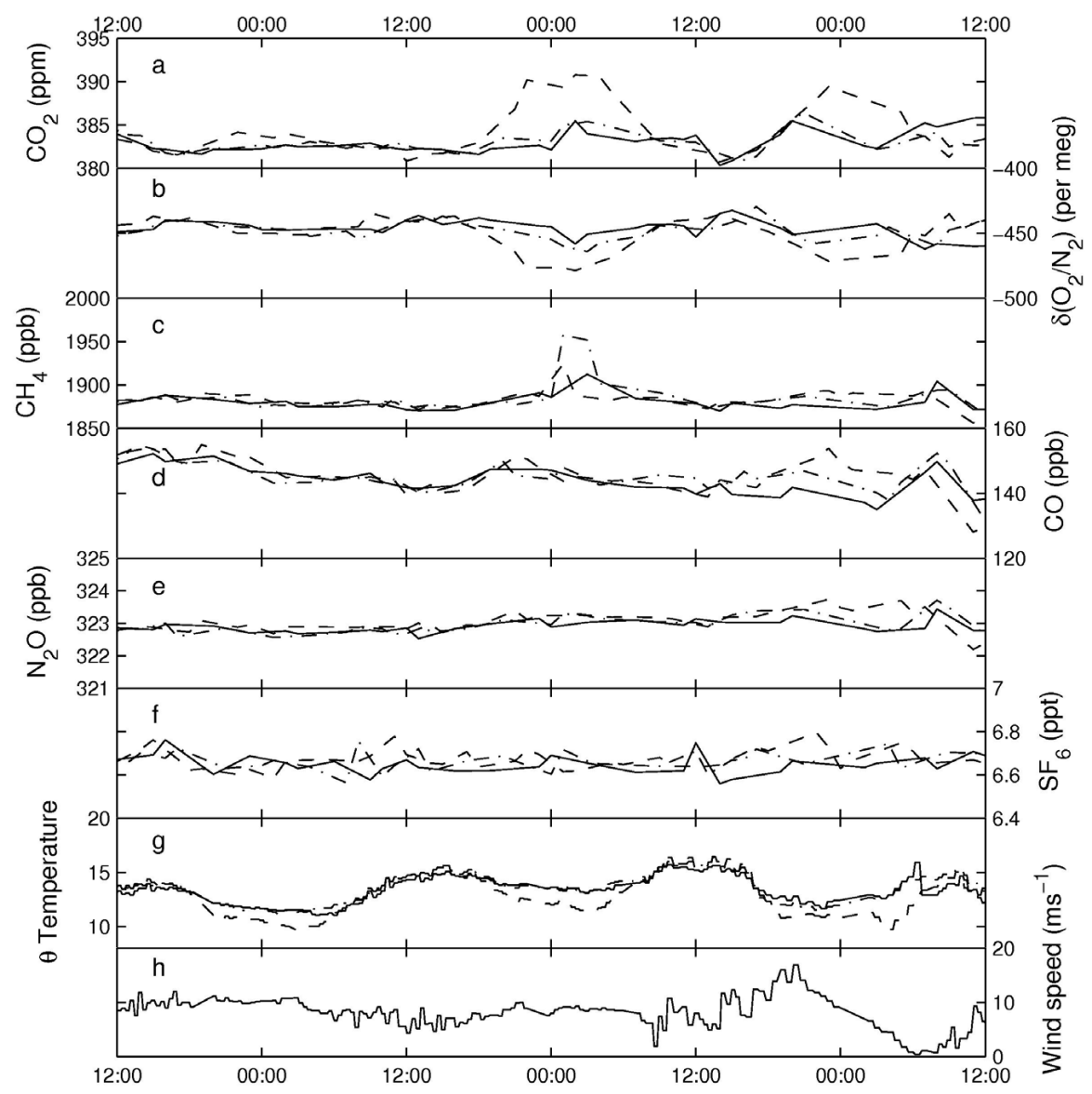

Fig. 5. Diurnal cycles of (a) $\mathrm{CO}_{2}$, (b) $\mathrm{O}_{2}$, (c) $\mathrm{CH}_{4}$, (d) $\mathrm{CO}$, (e) $\mathrm{N}_{2} \mathrm{O}$, (f) $\mathrm{SF}_{6}$, (g) potential temperature and (h) wind speed, shown at $163 \mathrm{~m}$ (solid), $90 \mathrm{~m}$ (dash-dot), and $23 \mathrm{~m}$ (dash) on the tower, from 11-14 May 2008. The mixing ratio data are hourly averages and the temperature and wind speed data are 2 min averages.

draw-down of $\mathrm{CO}_{2}$ occurs, and thus appears to represent the mixing ratio of the entraining free-tropospheric air.

The diurnal cycle of $\mathrm{CO}_{2}$ varies with season, as it is also modulated by changes in flux. Figure 7 illustrates the variation in the amplitude of the $\mathrm{CO}_{2}$ diurnal cycle at each height by month for 2007. During the winter months, the amplitude is smaller, consistent with little or no diurnal variation in the terrestrial fluxes, whereas during the growing season, the amplitude is larger as the contribution of diurnal variations in the terrestrial biosphere fluxes becomes important. At $163 \mathrm{~m}$, the amplitude is smaller than at $90 \mathrm{~m}$ and $23 \mathrm{~m}$ as it is generally above the nocturnal boundary layer. Furthermore, there appears to be a phase-lag at $163 \mathrm{~m}$ from October to January, and in February, the shape of the diurnal cycle is quite different from the lower levels. The differences in signals occur in the coolest months of the year, which suggests that they may be due to the following: 1) night-time subsidence (owing to cold surface temperatures) leading to an inflow of air from above the nocturnal boundary, and hence, a depression in the $\mathrm{CO}_{2}$ mixing ratio at night-time at $163 \mathrm{~m}$, and 2) transport of air from upstream of Ochsenkopf that contains remnants of the previous night's nocturnal boundary layer leading to a $\mathrm{CO}_{2}$ peak at $163 \mathrm{~m}$ in the late morning to noon.

\subsection{Synoptic variability}

In this section, we present a case study of a synoptic event from 18-19 September 2006 and, with the use of a regional transport model, examine how such synoptic variability may be used to determine spatiotemporal patterns in the fluxes of trace gases and, thus, how useful it would be in atmospheric inversions for the quantitative estimation of fluxes on regional scales. The transport model used is STILT (Stochastic Time-Inverted Lagrangian Transport) and was developed by Lin et al. (2003). STILT was driven with meteorological data from ECMWF (0:00 and 12:00 analysis fields combined with short term forecast fields), which have a temporal resolution of 3-hours and a spatial resolution of $1 / 4$ degree in latitude and longitude. The STILT model itself has a dynamic resolution, with the finest grid being $1 / 12$ degree latitude by 


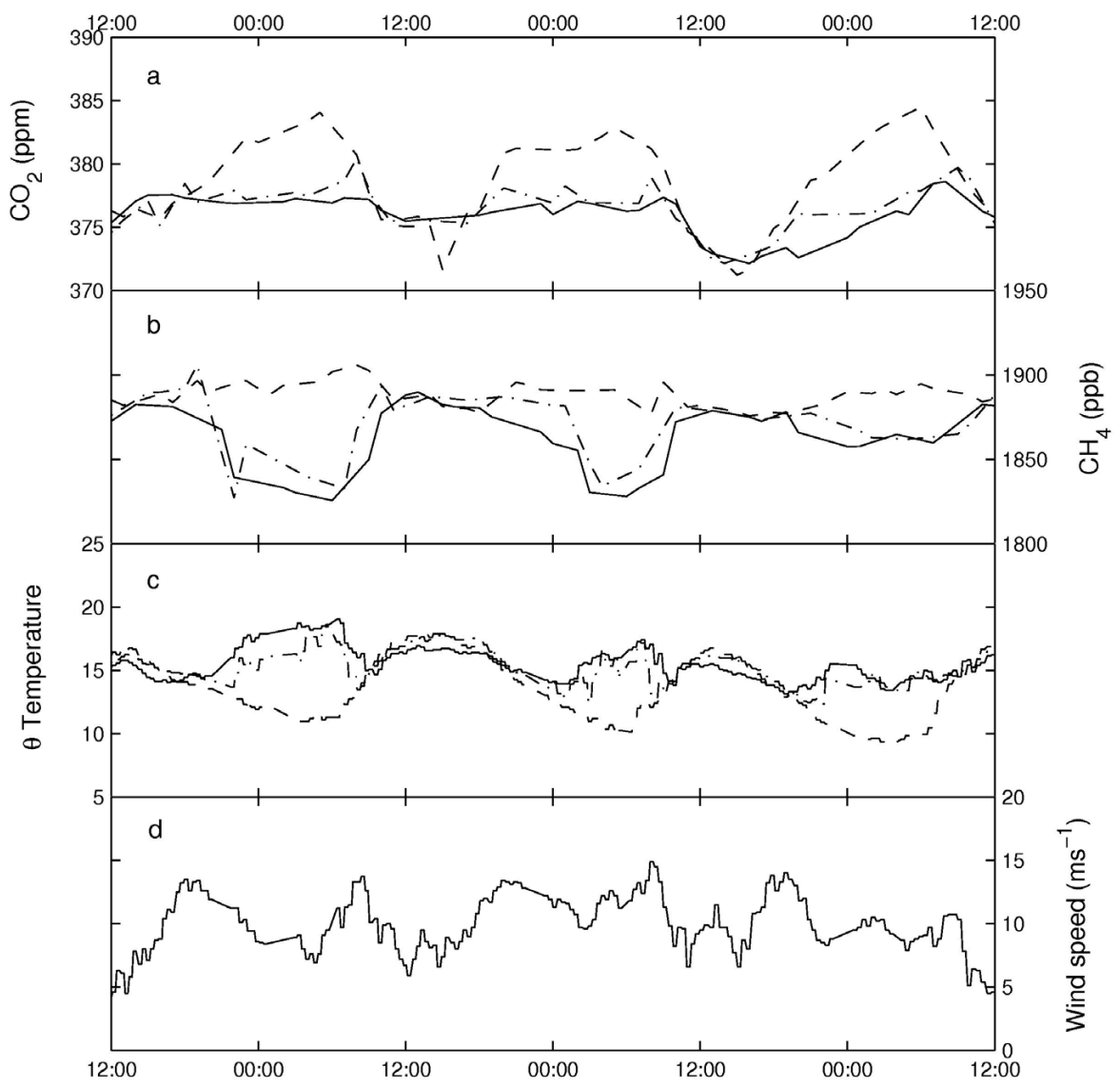

Fig. 6. Diurnal cycles of (a) $\mathrm{CO}_{2}$, (b) $\mathrm{CH}_{4}$, (c) potential temperature, and (d) wind speed, shown at $163 \mathrm{~m}$ (solid), $90 \mathrm{~m}$ (dash-dot), and $23 \mathrm{~m}$ (dash) on the tower, from 21-24 September 2006. The mixing ratio data are hourly averages and the temperature and wind speed data are 2 min averages.

$1 / 8$ degree longitude, that increases with the size of the footprint area to reduce computational time as well as preventing under sampling of surface fluxes at times when the footprint area is very large (Gerbig et al., 2003). The model domain was chosen for Europe, extending from $35^{\circ} \mathrm{N}$ to $62^{\circ} \mathrm{N}$ and $168^{\circ} \mathrm{W}$ to $35^{\circ} \mathrm{E}$.

Figure 8 shows the development in the mixing ratios of $\mathrm{CO}_{2}, \mathrm{CH}_{4}, \mathrm{CO}$ and $\mathrm{N}_{2} \mathrm{O}$ during the event. The mixing ratios of these gases increased significantly on 18 September, reaching a maximum early on 19 September before dropping off rapidly. These changes were driven by atmospheric transport variations as well as by heterogeneity in the fluxes. We used the STILT model to account for the atmospheric transport and to determine the areas where the fluxes had the greatest influence on the mixing ratios at different times during the event, namely, at the start, peak, and end of the event. In other words, we calculated the surface influence or "footprint" (which has dimensions of mixing ratio divided by flux e.g. $\mathrm{ppb} / \mu \mathrm{mol} \mathrm{m}{ }^{-2} \mathrm{~s}^{-1}$ ) over 10 days backwards in time from Ochsenkopf. At the beginning of the event (18 September, 00:00), there is a small area of strong influence south- east of Ochsenkopf but a much larger area of weaker influence over south-east Europe and the Mediterranean (Fig. 9a). The peak (19 September, 00:00) coincides with a stagnation event, with the area of strongest influence coinciding with the densely populated and industrialised regions of Hessen and Nordrhein-Westfalen, in western and north-western Germany (Fig. 9b). At the end of the event (20 September, 00:00) the air is being transported from the west and the area of strongest influence is in a thin band west of Ochsenkopf and with weaker influence from northern France and the Atlantic Ocean (Fig. 9c).

The STILT model was also used to simulate the mixing ratios by advecting a priori flux estimates of the trace gases, to investigate how atmospheric transport of these fluxes would influence the observations at Ochsenkopf. The anthropogenic fluxes used were from the IER dataset (Europe only) with a spatial resolution of $10 \mathrm{~km} \times 10 \mathrm{~km}$ and hourly temporal resolution (Friedrich et al., 2003). For $\mathrm{CO}_{2}$, the natural fluxes were from VPRM (Vegetation Photosynthesis and Respiration Model), which is an assimilation scheme that uses the Enhanced Vegetation Index (EVI) and Land Surface 


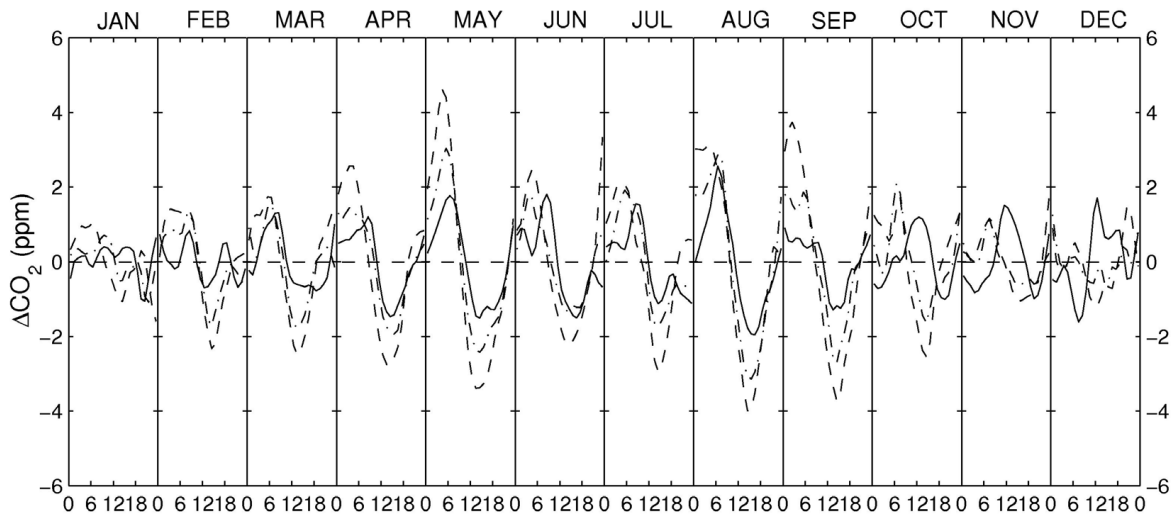

Fig. 7. Monthly mean diurnal cycles of $\mathrm{CO}_{2}$ shown for each month of 2007 at $163 \mathrm{~m}$ (solid), $90 \mathrm{~m}$ (dash-dot), and $23 \mathrm{~m}$ (dash). (For the calculation, at least 20 days of data were averaged for each month, except for January when only 14 days of data were available.)

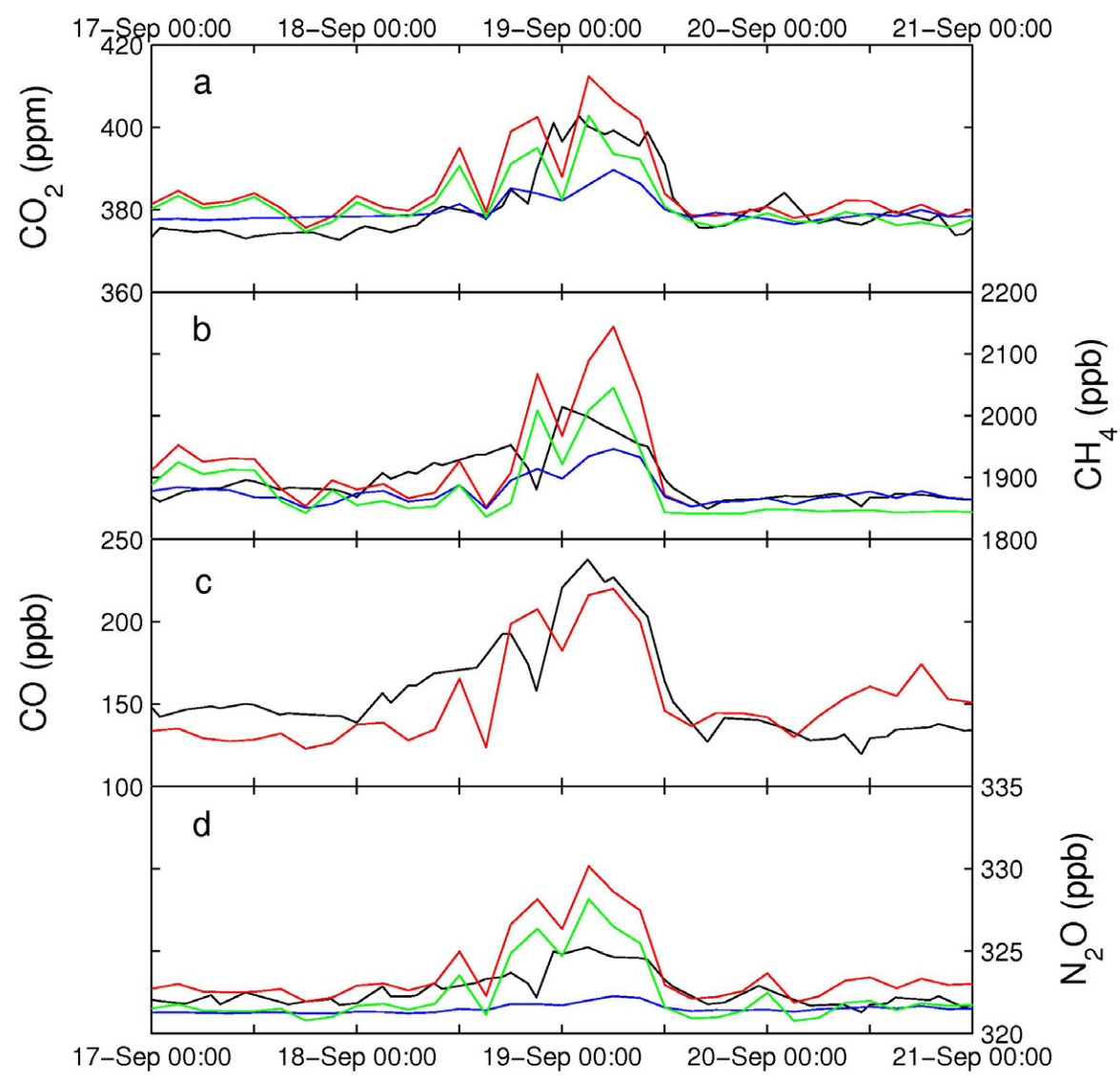

Fig. 8. Change in mixing ratios of (a) $\mathrm{CO}_{2}$, (b) $\mathrm{CH}_{4}$, (c) $\mathrm{CO}$ and (d) $\mathrm{N}_{2} \mathrm{O}$. The observed mixing ratios (black) are hourly averages from $163 \mathrm{~m}$ level. Also shown are the simulated mixing ratios at 3-hourly intervals, these are the total (red), biospheric (green) and anthropogenic (blue).

Water Index (LSWI) from satellite observations plus high resolution sunlight and air temperature data (Mahadevan et al., 2008). VPRM has a spatial resolution of $1 \mathrm{~km} \times 1 \mathrm{~km}$ and hourly temporal resolution. For natural fluxes of $\mathrm{CH}_{4}$ and $\mathrm{N}_{2} \mathrm{O}$, we used data from the Global Emissions Inventory Ac- tivity (GEIA) at $1 \times 1$ degree resolution, which has monthly resolution for $\mathrm{CH}_{4}$ (Fung et al., 1991) and no temporal variability for $\mathrm{N}_{2} \mathrm{O}$ (Olivier et al., 1998). For CO, the biospheric emissions are negligible and, hence, are not modelled. 
The comparison of the observed with the simulated mixing ratios is shown in Fig. 8. Simulations using separate anthropogenic and biospheric fluxes are also shown to illustrate how each of these contributes to the total. For CO, the total is that of the anthropogenic emissions (i.e. fossil fuel combustion). Until 18 September, 12:00, the biospheric fluxes contributed most to the total $\mathrm{CO}_{2}$ mixing ratio. After this time, there was a transition to stronger influence from industrialised western Germany and consequently an increase in the anthropogenic flux contribution, which reached a peak during the time of stagnation (19 September, 00:00). Moreover, although the mixing ratios of all components increased, most likely owing to a shallower mixed layer, the fraction of the anthropogenic contribution increased. A similar development in the mixing ratios is also seen in $\mathrm{CH}_{4}$. For $\mathrm{N}_{2} \mathrm{O}$, however, the biospheric fluxes still contributed the most to the total mixing ratio; even during stagnation the contribution from anthropogenic fluxes increased only slightly. For $\mathrm{N}_{2} \mathrm{O}$, fluxes from soils under natural vegetation and from agricultural soils are both attributed to the biospheric flux (that is represented by the green curve). This forms the largest $\mathrm{N}_{2} \mathrm{O}$ source, and it can be seen that even while the area of strongest influence was a densely populated and industrial one, this flux still dominated the signal. (The anthropogenic flux is that from industry, fossil fuel combustion and waste). In the case of $\mathrm{CO}$, the mixing ratio is captured quite well using the anthropogenic fluxes.

The change in influence from predominantly biospheric to both anthropogenic and biospheric fluxes is also supported by the observed change in the ratio of atmospheric $\mathrm{O}_{2}$ to $\mathrm{CO}_{2}$. From 17 September, 00:00 to 18 September, 09:00, the $\mathrm{O}_{2}: \mathrm{CO}_{2}$ ratio was $1.08 \pm 0.13\left(R^{2}=0.45\right)$, whereas from 18 September, 18:00 to 19 September, 12:00 the ratio was $1.16 \pm 0.04\left(R^{2}=0.94\right)$. The ratio of the change in $\mathrm{O}_{2}$ to $\mathrm{CO}_{2}$ is a well established indicator for the dominant process that is influencing the mixing ratios, for example, photosynthesis and respiration result in an $\mathrm{O}_{2}: \mathrm{CO}_{2}$ ratio of about 1.0 to 1.1 (Seibt et al., 2004; Severinghaus, 1995), while fossil fuel combustion results in a larger ratio with reported ratios of 1.95 for natural gas, 1.44 for liquid fuels, 1.17 for coal and a global weighted average of about 1.4 (Keeling, 1988; Manning and Keeling, 2006).

As this case study shows, the synoptic scale variability in mixing ratios at Ochsenkopf is determined by changes in atmospheric transport and vertical mixing as well as by the spatial heterogeneity of fluxes. Footprint analyses, such as those shown here, are useful to determine which areas had the greatest influence on the observations and to help understand the causes of synoptic variability.

\subsection{Annual footprint estimate}

Using STILT, we determined the total footprint for the year 2007 at $163 \mathrm{~m}$ above ground level (Fig. 10). The total footprint is the sum of all footprints over the year (at 3 hourly in- a)
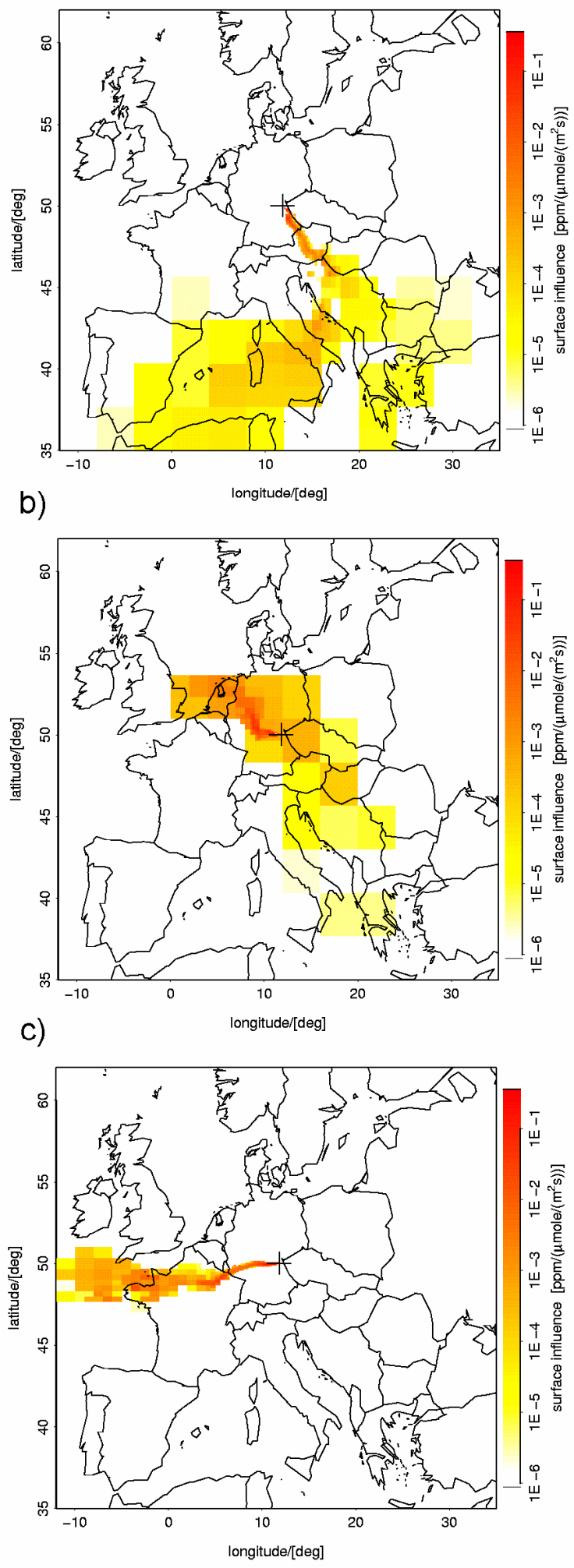

Fig. 9. Footprints of the Ochsenkopf tower in units of $\mathrm{ppm} / \mu \mathrm{mol} \mathrm{m} \mathrm{m}^{-2} \mathrm{~s}^{-1}$ (logarithmic scale) for (a) 18 September 2006, 00:00, (b) 19 September 2006, 00:00, and (c) 20 September 2006, 00:00. 

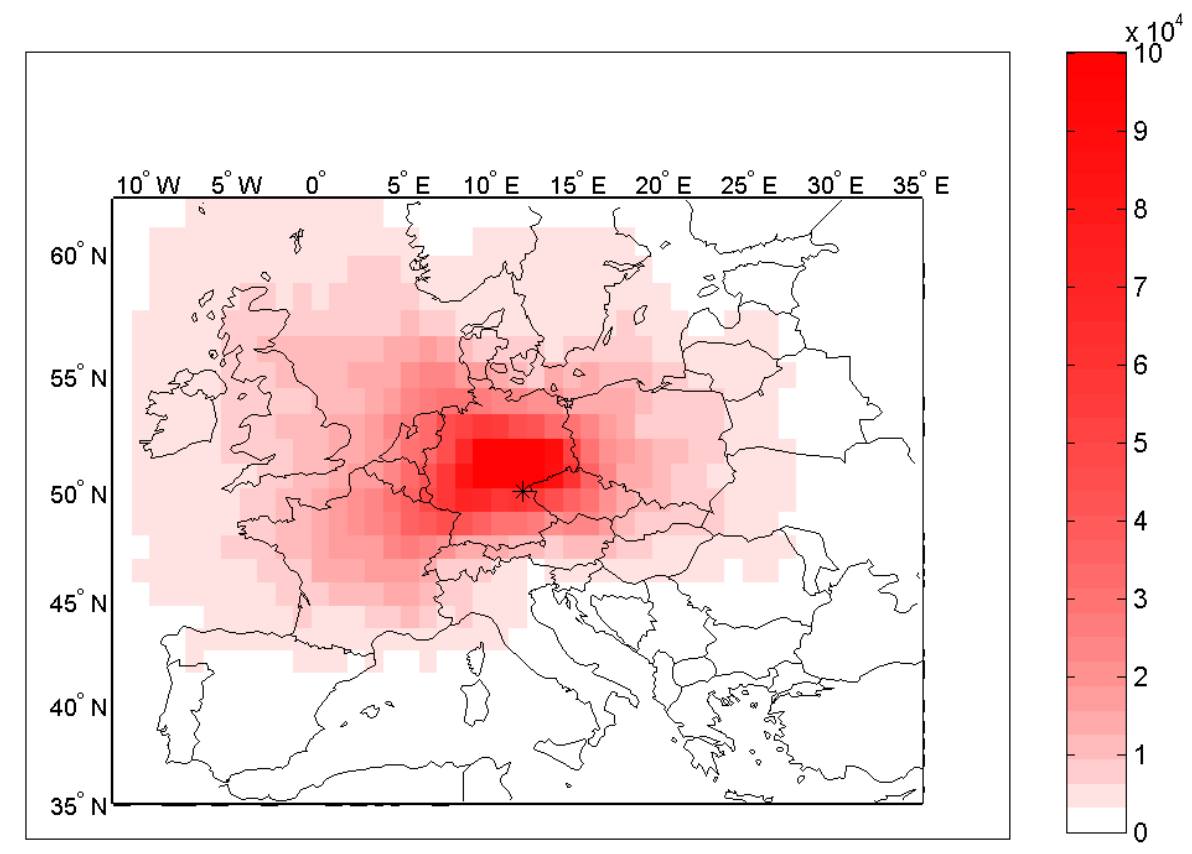

Fig. 10. Total annual footprint of Ochsenkopf tall tower (at $163 \mathrm{ma.g} .1$.) for 2007 shown at $1 \times 1$ degree resolution (units of $\left.\mathrm{ppb} / \mu \mathrm{mol} \mathrm{m}^{-2} \mathrm{~s}^{-1}\right)$. Areas in white have a surface influence of $<1 \%$ of the maximum. The position of Ochsenkopf is indicated by $*$.

tervals), each of which was calculated for 10 days backwards in time from Ochsenkopf. For each of the individual footprints, the surface influences (units of $\mathrm{ppb} / \mu \mathrm{mol} \mathrm{m}^{-2} \mathrm{~s}^{-1}$ ) were aggregated into $1 \times 1$ degree grid cells, to give the total footprint at this resolution. In Fig. 10, the total footprint is shown using white for areas where the surface influence was less than $1 \%$ of the maximum. One can see that the surface influence falls sharply with distance from Ochsenkopf. Also notable, is that the influence from the north and west is stronger than that from the south and east of Ochsenkopf, which is a result of atmospheric circulation. Ochsenkopf's footprint (using a cut-off at $1 \%$ of the maximum) extends over an area of approximately $10^{6} \mathrm{~km}^{2}$, covering a large part of central and western Europe.

\section{Summary and conclusions}

Ochsenkopf tall tower has been running continuously since mid-2006 and we have presented an approximately 2.5 year record of in-situ measurements of $\mathrm{CO}_{2}, \mathrm{O}_{2}, \mathrm{CH}_{4}, \mathrm{CO}, \mathrm{N}_{2} \mathrm{O}$ and $\mathrm{SF}_{6}$ mixing ratios. In addition, $\mathrm{H}_{2}$ mixing ratio and stable isotope data, for $\delta^{13} \mathrm{C}$ and $\delta^{18} \mathrm{O}$ in $\mathrm{CO}_{2}$, are available from flask samples collected at Ochsenkopf at approximately weekly intervals. From this relatively short record, the seasonal cycles of these gas species have been characterized and the shape, phase and amplitude were determined for 20062008. Although it is not possible to see inter-annual variability in these gases over this time period, the multi-annual trends have been determined. On average $\mathrm{CO}_{2}$ increased by $1.60 \mathrm{ppm} / \mathrm{yr}$ and $\mathrm{O}_{2}$ decreased by $16.3 \mathrm{per} \mathrm{meg} / \mathrm{yr}$. $\mathrm{CH}_{4}$ increased substantially $(9.8 \mathrm{ppb} / \mathrm{yr})$; a rate much higher than the global mean has been since 1999 but consistent with recent observations of a renewed increase in the global growthrate since the beginning of 2007. An increase in $\mathrm{N}_{2} \mathrm{O}$ mixing ratio was also observed $(0.99 \mathrm{ppb} / \mathrm{yr})$ and was close to the global mean growth-rate in 2006.

Diurnal cycles were visible in $\mathrm{CO}_{2}$ and $\mathrm{O}_{2}$ but were only rarely seen in the other trace gases. For $\mathrm{CO}_{2}$ and $\mathrm{O}_{2}$, these were modulated by diurnal variations in the biosphere fluxes as well as by changes in vertical mixing. The occasional diurnal variations in $\mathrm{CH}_{4}, \mathrm{CO}$, and $\mathrm{N}_{2} \mathrm{O}$ occurred when the night-time conditions were very stable, that is, when there was little convective mixing, which resulted in significant accumulation in the nocturnal boundary layer. Occasions when the night-time increase was stronger at the $23 \mathrm{~m}$ level than at $90 \mathrm{~m}$ most likely resulted from sources in the nearfield. Atmospheric mixing at Ochsenkopf is influenced by the mountain-valley terrain, and subsidence as well as upslope and down-slope winds can influence the observed mixing ratios. Moreover, the $163 \mathrm{~m}$ level on the tower generally remains above the nocturnal boundary layer, and thus, observations from this height exhibit only weak diurnal cycles in $\mathrm{CO}_{2}$ and $\mathrm{O}_{2}$.

On the whole, the synoptic scale variability is stronger than the diurnal variability at Ochsenkopf. The synoptic variability of $\mathrm{CO}_{2}, \mathrm{O}_{2}, \mathrm{CH}_{4}$ and $\mathrm{N}_{2} \mathrm{O}$ has contributions from anthropogenic as well as natural fluxes and is driven by 
changes in atmospheric transport and mixing. The synoptic changes in mixing ratio at Ochsenkopf contain valuable information that could be used to constrain fluxes for western and central Europe. However, this information could be greatly enhanced with a better understanding of the influence that mountain-valley terrain has on atmospheric mixing. Measurement campaigns using aircraft would help tremendously with this, while also showing how observations at the site relate to mixing ratios in the boundary layer around Ochsenkopf. This information would facilitate more meaningful comparisons of Ochsenkopf observations with simulations from coarse-grid models and indicate how these observations may be best included in atmospheric inversions.

Acknowledgements. We thank W. Brand, R. Leppert, K. Kübler, B. Schlöffel, F. Voigt, S. Baum, S. Schmidt, and J. Seyffreth (MPI-BGC) for their help with setting up and/or for supporting the Ochsenkopf station. MPI-BGC would like to acknowledge the on-going support from the Bayerischer Rundfunk (BRF) who own the Ochsenkopf tower and, in particular, from B. Heerdt (BRF). We are also very grateful to $\mathrm{C}$. Gerbig for introducing us to the STILT model. We thank B. Stephens (NCAR, USA) for advice on setting up the Oxzilla $\mathrm{O}_{2}$ analyser and we thank R. Robertson for collecting the flask samples at the Shetland Islands. The Ochsenkopf measurements are partly funded by the European Union projects, CarboEurope (Ref. No. GOCE-CT-2003-505572) and CHIOTTO (Ref. No. EVK2-CT-2002-00163). A. C. Manning is supported by a UK NERC/QUEST Advanced Fellowship (Ref. No. NE/C002504/1).

The service charges for this open access publication have been covered by the Max Planck Society.

Edited by: S. Reimann

\section{References}

Bakwin, P. S., Tans, P. P., Zhao, C., Ussler, W., and Quesnell, E.: Measurements of carbon dioxide on a very tall tower, Tellus, 47B, 535-549, 1995.

Bakwin, P. S., Tans, P. P., Hurst, D. F., and Zhao, C.: Measurements of carbon dioxide on very tall towers: results of the NOAA/CMDL program, Tellus, 50B, 401-415, 1998.

Bousquet, P., Ciais, P., Miller, J. B., Dlugokencky, E. J., Hauglustaine, D. A., Prigent, C., Van der Werf, G. R., Peylin, P., Brunke, E. G., Carouge, C., Langenfelds, R. L., Lathiere, J., Papa, F., Ramonet, M., Schmidt, M., Steele, L. P., Tyler, S. C., and White, J.: Contribution of anthropogenic and natural sources to atmospheric methane variability, Nature, 443, 439-443, 2006

Broecker, W. S. and Peng, T. H.: Gas exchange rates between air and sea, Tellus, 26, 21-35, 1974.

Denman, K. L., Brasseur, G. P., Chidthaisong, A., Ciais, P., Cox, P. M., Dickinson, R. E., Hauglustaine, D., Heinze, C., Holland, E., Jacob, D., Lohmann, U., Ramachandran, S., da Silva Dias, P. L., Wofsy, S. C., and Zhang, X.: Couplings Between Changes in the Climate System and Biogeochemistry, in: Climate Change 2007: The Physical Science Basis, Contribution of Working Group I to the Fourth Assessment Report of the Intergovernmental Panel on Climate Change, edited by: Solomon, S. D., Qin, D., Manning,
M., Chen, Z., Marquis, M., Averyt, K. B., Tignor, M., and Miller, H. L., Cambridge University Press, Cambridge, 2007.

Dlugokencky, E. J., Steele, L. P., Lang, P. M., and Masarie, K. A.: The Growth-Rate and Distribution of Atmospheric Methane, J. Geophys. Res.-Atmos., 99, 17021-17043, 1994.

Dushman, S.: Scientific foundations of Vacuum Technique, John Wiley, 806 pp., 1962

Forster, P., Ramaswamy, V., Artaxo, P., Berntsen, T., Betts, R., Fahey, D. W., Haywood, J., Lean, J., Lowe, D. C., Myhre, G., Nganga, J., Prinn, R., Raga, G., Schultz, M., and Van Dorland, R.: Changes in Atmospheric Constituents and in Radiative Forcing, in: Climate Change 2007: The Physical Science Basis, Contribution of Working Group I to the Fourth Assessment Report of the Intergovernmental Panel on Climate Change, edited by: Solomon, S., Qin, D., Manning, M., Chen, Z., Marquis, M., Averyt, K. B., Tignor, M., and Miller, H. L., Cambridge University Press, Cambridge, UK, 2007.

Friedrich, R., Freibauer, A., Gallman, E., Giannouli, M., Koch, D., Peylin, P., Pye, S., Riviere, E., San Jose, R., Winiwarter, W., Blank, P., Kühlwein, J., Pregger, T., Reis, S., Scholz, Y., Theloke, J., and Vabitsh, A.: Temporal and Spatial Resolution of Greenhouse Gas Emissions in Europe, Institut für Energiewirtschaft und Rationelle Energieanwendung, Universität Stuttgart, Stuttgart, 36 pp., 2003.

Fung, I., John, J., Lerner, J., Matthews, E., Prather, M., Steele, L. P., and Fraser, P. J.: Three-dimensional model synthesis of the global methane cycle, J. Geophys. Res., 96, 13033-13065, 1991.

Fung, I. Y., Tucker, C. J., and Prentice, K. C.: Application of Advanced Very High Resolution Radiometer Vegetation Index to Study Atmosphere-Biosphere Exchange of $\mathrm{CO}_{2}$, J. Geophys. Res., 92, 2999-3015, 1987.

Gerbig, C., Lin, J. C., Wofsy, S. C., Daube, B. C., Andrews, A. E., Stephens, B. B., Bawkin, P., and Grainger, C. A.: Toward constraining regional-scale fluxes of $\mathrm{CO}_{2}$ with atmospheric observations over a continent: 2. Analysis of COBRA data using a receptor-orientated framework, J. Geophys. Res., 108(D24), 4757, doi:10.1029/2003JD003770, 2003.

Gerbig, C., Lin, J. C., Munger, J. W., and Wofsy, S. C.: What can tracer observations in the continental boundary layer tell us about surface-atmosphere fluxes?, Atmos. Chem. Phys., 6, 539-554, 2006 ,

http://www.atmos-chem-phys.net/6/539/2006/.

Gloor, M., Fan, S., Pacala, S., and Sarmiento, J.: Optimal sampling of the atmosphere for purpose of inverse modeling: A model study, Global Biogeochem. Cy., 14, 407-428, 2000.

Gloor, M., Bakwin, P., Hurst, D., Lock, L., Draxler, R., and Tans, P. P.: What is the concentration footprint of a tall tower?, J. Geophys. Res., 106, 17831-17840, 2001.

Haszpra, L., Barcza, Z., Bakwin, P. S., Berger, B. W., Davis, K. J., and Weidinger, T.: Measuring system for the long-term monitoring of biosphere/atmosphere exchange of carbon dioxide, J. Geophys. Res.-Atmos., 106, 3057-3069, 2001.

Haszpra, L., Barcza, Z., Hidy, D., Szilágyi, I., Dlugokencky, E. J., and Tans, P. P.: Trends and temporal variations of major greenhouse gases at a rural site in Central Europe, Atmos. Environ., 42, 8707-8716, 2008

Hurst, D. F., Bawkin, P. S., Myers, R. C., and Elkins, J. W.: Behaviour of trace gas mixing ratios on a very tall tower, J. Geophys. Res., 102, 8825-8835, 1997. 
Jiang, X., Ku, W. L., Shia, R., Li, Q., Elkins, J. W., Prinn, R. G., and Yung, Y. L.: Seasonal cycle of $\mathrm{N}_{2} \mathrm{O}$ : Analysis of data, Global Biogeochem. Cy., 21, GB1006, doi:10.1029/2006GB002691, 2007.

Jordan, A., Manning, A., Schultz, U., and Seifert, T.: Continuous GC Measurements of Trace Gases at the Ochsenkopf Monitoring Station, in: WMO-GAW Report, Proceedings of the 12th IAEA/WMO meeting of $\mathrm{CO}_{2}$ experts, Toronto, 2003, edited by: Worthy, D. and Huang, L., 191-194, 2005.

Keeling, C. D., Chin, J. F. S., and Whorf, T. P.: Increased activity of northern vegetation inferred from atmospheric $\mathrm{CO}_{2}$ measurements, Nature, 382, 146-149, 1996.

Keeling, R. F.: Development of an interferometric oxygen analyzer for precise measurement of the atmospheric $\mathrm{O}_{2}$ mole fraction, Ph.D. thesis, Harvard University, Cambridge, Massachusetts, USA, 178 pp., 1988.

Keeling, R. F. and Shertz, S. R.: Seasonal and inter-annual variations in atmospheric oxygen and implications for the global carbon cycle, Nature, 358, 723-727, 1992.

Keeling, R. F., Manning, A., McEvoy, E. M., and Shertz, S. R.: Methods for measuring changes in atmospheric $\mathrm{O}_{2}$ concentration and their application in southern hemisphere air, J. Geophys. Res., 103, 3381-3407, 1998.

Keeling, R. F., Manning, A. C., Paplawsky, W. J., and Cox, A. C.: On the long-term stability of reference gases for atmospheric $\mathrm{O}_{2} / \mathrm{N}_{2}$ and $\mathrm{CO}_{2}$ measurements, Tellus, 59B, 3-14, 2007.

Kozlova, E. A., Manning, A. C., Kisilyakhov, Y., Seifert, T., and Heimann, M.: Seasonal, synoptic, and diurnal-scale variability of biogeochemical trace gases and $\mathrm{O}_{2}$ from a $300 \mathrm{~m}$ tall tower in central Siberia, Global Biogeochem. Cy., 22, GB4030, doi:10.1029/2008GB003209, 2008.

Kozlova, E. A. and Manning, A. C.: Methodology and calibration for continuous measurements of biogeochemical trace gas and $\mathrm{O}_{2}$ concentrations from a $300 \mathrm{~m}$ tall tower in central Siberia, Atmos. Meas. Tech., 2, 205-220, 2009, http://www.atmos-meas-tech.net/2/205/2009/.

Langenfelds, R., Francey, R., Pak, B. C., Steele, L. P., Lloyd, J., Trudinger, C. M., and Allison, C. E.: Interannual growth rate variations of atmospheric $\mathrm{CO}_{2}$ and its $\delta^{13} \mathrm{C}, \mathrm{H}_{2}, \mathrm{CH}_{4}$, and $\mathrm{CO}$ between 1992 and 1999 linked to biomass burning, Global Biogeochem. Cy., 16, 1048, doi:1010.1029/2001GB001466, 2002.

Langenfelds, R. L., Francey, R. J., Steele, L. P., Spencer, D. A., and Dunse, B. L.: Flask sampling from Cape Grim overflights, Bureau of Meteorology and CSIRO Atmospheric Research, Melbourne, 74-84, 2001.

Langenfelds, R. L., van der Schoot, M. V., Francey, R. J., Steele, L. P., Schmidt, M., and Mukai, H.: Modification of air standard composition by diffusive and surface processes, J. Geophys. Res., 110, D13307, doi:10.1029/2004JD005482, 2005.

Law, R. M., Rayner, P. J., Steele, L. P., and Enting, I. G.: Using high temporal frequency data for $\mathrm{CO}_{2}$ inversions, Global Biogeochem. Cy., 16, 1053, doi:10.1029/2001GB001593, 2002.

Levin, I., Ciais, P., Langenfelds, R., Schmidt, M., Ramonet, M., Sidorov, K., Tchebakova, N., Gloor, M., Heimann, M., Schultze, E. D., Vygodskaya, N. N., Shibistova, O., and Lloyd, J.: Three years of trace gas observations over the European-Siberian domain derived from aircraft sampling - A concerted action, Tellus Series B, 54, 696-712, 2002.

Liao, T., Camp, C. D., and Yung, Y. L.: The seasonal cycle of $\mathrm{N}_{2} \mathrm{O}$,
Geophys. Res. Lett., 40, 1003, doi:10.1029/2000RG000092, 2004.

Lin, J. C., Gerbig, C., Wofsy, S. C., Andrews, A. E., Daube, B. C., Davis, K. J., and Grainger, C. A.: A near-field tool for simulating the upstream influence of atmospheric observations: The Stochastic Time-Inverted Lagrangian Transport (STILT) model, J. Geophys. Res., 108, 4493, doi:10.1029/2002JD003161, 2003.

Logan, J. A., Prather, M. J., Wofsy, S. C., and McElroy, M. B.: Tropospheric chemistry: A global perspective, J. Geophys. Res., 86, 7210-7254, 1981.

Machta, L. and Hughes, E.: Atmospheric oxygen in 1967 to 1970, Science, 168, 1582-1584, 1970.

Mahadevan, P., Wofsy, S. C., Matross, D. M., Xiao, X., Dunn, A. L., Lin, J. C., Gerbig, C., Munger, J. W., Chow, V. Y., and Gottlieb, E. W.: A satellite-based biosphere parameterization for net ecosystem $\mathrm{CO}_{2}$ exchange: Vegetation Photosynthesis and Respiration Model (VPRM), Global Biogeochem. Cy., 22, GB2005, doi:10.1029/2006GB002735, 2008.

Manning, A. C.: Temporal variability of atmospheric oxygen from both continuous measurements and a flask-sampling network: Tools for studying the global carbon cycle, Ph.D. thesis, Scripps Institution of Oceanography, University of California, San Diego, 202 pp., 2001.

Manning, A. C. and Keeling, R. F.: Global oceanic and land biotic carbon sinks from the Scripps atmospheric oxygen flask sampling network, Tellus, 58B, 95-116, 2006.

Mastepanov, M., Sigsgaard, C., Dlugokencky, E. J., Houweling, S., Ström, L., Tamstorf, M. P., and Christensen, T. R.: Large tundra methane burst during onset of freezing, Nature, 456, 628-630, doi:10.1038/nature07464, 2008.

Nevison, C. D., Lueker, T. J., and Weiss, R. F.: Quantifying the nitrous oxide source from coastal upwelling, Global Biogeochem. Cy., 18, GB1018, doi:10.1029/2003GB002110, 2004.

Olivier, J. G. J., Bouwman, A. F., Van der Hoek, K. W., and Berdowski, J. J. M.: Global air emission inventories for anthropogenic sources of $\mathrm{NO}_{\mathrm{x}}, \mathrm{NH}_{3}$ and $\mathrm{N}_{2} \mathrm{O}$ in 1990, Environ. Pollut., 102, 135-148, 1998.

Popa, E.: Continuous tall tower multi-species measurements in Europe for quantifying and understanding land-atmosphere carbon exchange, Ph.D. thesis, Friedrich Schiller University, Jena, 2008.

Popa, E., Gloor, M., Manning, A. C., Jordan, A., Schultz, U., Hänsel, F., Seifert, T., and Heimann, M.: Measurements of greenhouse gases and related tracers at Bialystok tall tower station in Poland, submitted to Atmos. Meas. Tech. Discuss., 2009.

Rigby, M., Prinn, R. G., Fraser, P. J., Simmonds, P. G., Langenfelds, R. L., Huang, J., Cunnold, D. M., Steele, L. P., Krummel, P. B., Weiss, R. F., O’Doherty, S., Salameh, P. K., Wang, H. J., Harth, C. M., Mühle, J., and Porter, L. W.: Renewed growth of atmospheric methane, Geophys. Res. Lett., 35, L22805, doi:10.1029/2008GL036037, 2008.

Rothe, M., Jordan, A., and Brand, W. A.: Trace gases, $\delta^{13} \mathrm{C}$ and $\delta^{18} \mathrm{O}$ of $\mathrm{CO}_{2}$ in air samples: Storage in glass flasks using PCTFE seals and other effects, 12th IAEA/WMO meeting of $\mathrm{CO}_{2}$ experts, Toronto, 2003, edited by: Worthy, D. E. and Huang, L., 64-70, 2005.

Schmidt, M., Messager, C., Ramonet, M., Wastine, B., Yver, C., Vuillemin, C., Grand, M., Kaiser, C., Parmentier, E., Cloue, O., and Ciais, P.: Two years of high-precision quasi-continuous atmospheric greenhouse gas measurements at Trainou Tower 
(Orléans Forest, France), submitted, 2009.

Seibt, U., Brand, W. A., Heimann, M., Lloyd, J., Severinghaus, J. P., and Wingate, L.: Observations of $\mathrm{O}_{2}: \mathrm{CO}_{2}$ exchange ratios during ecosystem gas exchange, Global Biogeochem. Cy., 18, GB4024, doi:10.1029/2004GB002242, 2004.

Severinghaus, J. P.: Studies of the terrestrial $\mathrm{O}_{2}$ and carbon cycles in sand dune gases and in Biosphere 2, Ph.D. thesis, Columbia University, New York, 148 pp., 1995.

Stephens, B. B., Keeling, R. F., Heimann, M., Six, K. D., Murnane, R., and Caldeira, K.: Testing global ocean carbon cycle models using measurements of atmospheric $\mathrm{O}_{2}$ and $\mathrm{CO}_{2}$ concentration, Global Biogeochem. Cy., 12, 213-230, 1998.

Stephens, B. B., Bawkin, P., Tans, P. P., Teclaw, R., and Baumann, D.: Application of a differential fuel-cell analyzer for measuring atmospheric oxygen variations, J. Atmos. Ocean. Tech., 24, 8294, doi:10.1175/JTECH1959.1, 2007.

Sturm, P., Leuenberger, M., Sirignano, C., Neubert, R. E. M., Meijer, H. A. J., Langenfelds, R., Brand, W. A., and Tohjima, Y.: Permeation of atmospheric gases through polymer O-rings used in flasks for air sampling, J. Geophys. Res., 109, D04309, doi:10.1029/2003JD004073, 2004.

Tans, P. P., Bakwin, P. S., and Guenther, D. W.: A feasible Global Carbon Cycle Observing System: a plan to decipher today's carbon cycle based on observations, Global Change Biol., 2, 309318, 1996.
Thompson, R. L., Manning, A. C., Lowe, D. C., and Weatherburn, D. C.: A ship-based methodology for high precision atmospheric oxygen measurements and its application in the Southern Ocean region, Tellus, 59, 643-653, 2007.

Vermeulen, A. T., Pieterse, G., Hensen, A., van den Bulk, W. C. M., and Erisman, J. W.: COMET: a Lagrangian transport model for greenhouse gas emission estimation - forward model technique and performance for methane, Atmos. Chem. Phys. Discuss., 6, 8727-8779, 2006, http://www.atmos-chem-phys-discuss.net/6/8727/2006/.

Vermeulen, A. T., Hensen, A., Popa, E., van den Bulk, W. C. M., and Jongejan, P. A. C.: Greenhouse Gas Observations from Cabauw Tall Tower (1992-2008), submitted, 2009.

Worthy, D. E., Platt, J. A., Kessler, R., Ernst, M., and Racki, S.: The Greenhouse Gases Measurement Program, Measurement Procedures and Data Quality, Meteorological Service of Canada, 97 $120,2003$.

Worthy, D. E. J., Levin, I., Trivett, N. B. A., Kuhlmann, A. J., Hopper, J. F., and Ernst, M. K.: Seven years of continuous methane observations at a remote boreal site in Ontario, Canada, J. Geophys. Res.-Atmos., 103, 15995-16007, 1998. 